\title{
GABAergic Interneurons: Implications for Understanding Schizophrenia and Bipolar Disorder
}

\author{
Francine M. Benes, M.D., Ph.D. and Sabina Berretta, M.D.
}

A core component to corticolimbic circuitry is the GABAergic interneuron. Neuroanatomic studies conducted over the past century have demonstrated several subtypes of interneuron defined by characteristic morphological appearances in Golgi-stained preparations. More recently, both cytochemical and electrophysiological techniques have defined various subtypes of GABA neuron according to synaptic connections, electrophysiological properties and neuropeptide content. These cells provide both inhibitory and disinhibitory modulation of cortical and hippocampal circuits and contribute to the generation of oscillatory rhythms, discriminative information processing and gating of sensory information within the corticolimbic system. All of these functions are abnormal in schizophrenia. Recent postmortem studies have provided consistent evidence that a defect of GABAergic neurotransmission probably plays a role in both schizophrenia and bipolar disorder. Many now believe that such a disturbance may be related to a perturbation of early development, one that may result in a disturbance of cell migration and the formation of normal lamination. The ingrowth of extrinsic afferents, such as the mesocortical dopamine projections, may "trigger" the appearance of a defective GABA system, particularly under stressful conditions when the modulation of the dopamine system is likely to be altered. Based on the regional and subregional distribution of changes in GABA cells in schizophrenia and bipolar disorder, it has been postulated that the basolateral nucleus of the amygdala may contribute to these abnormalities through an increased flow of excitatory activity. By using "partial" modeling, changes in the GABA system remarkably similar to those seen in schizophrenia and bipolar disorder have been induced in rat hippocampus. In the years to come, continued investigations of the GABA system in rodent, primate and human brain and the characterization of changes in specific phenotypic subclasses of interneurons in schizophrenia and bipolar disorder will undoubtedly provide important new insights into how the integration of this transmitter system may be altered in neuropsychiatric disease.

[Neuropsychopharmacology 25:1-27, 2001] (c) 2001 American College of Neuropsychopharmacology. Published by Elsevier Science Inc.
KEY WORDS: Prefrontal; Anterior cingulate; Hippocampus; Neuroleptics; Dopamine; Serotonin

From the Laboratory for Structural Neuroscience, McLean Hospital (FMB, SB), Belmont, MA; and the Program in Neuroscience (FMB), Harvard Medical School, Boston, MA; and Department of Psychiatry (FMB, SB), Harvard Medical School, Boston, MA.

Address correspondence to: Francine M. Benes, M.D., Ph.D., McLean Hospital, 115 Mill Street, Belmont, MA 02478.

Received 28 September 2000; revised December 5, 2000; accepted December 6, 2000.
Neurons that express the compound, $\gamma$-aminobutyric acid (GABA), are broadly present throughout the central nervous system, although telencephalic structures, such as the cerebral cortex, show the most abundant quantities of this neurotransmitter (Jones 1987). In the discussion that follows, the anatomy and physiology of various types of GABAergic interneurons in the cortex and hippocampus will be discussed and related to recent postmortem studies implicating this transmitter system in the pathophysiology of schizophrenia and bi- 
polar disorder and their treatment with neuroleptic drugs (for more comprehensive reviews on cortical and hippocampal neurons see: Hof et al. 1993; Freund and Buzsaki 1996; Somogyi et al. 1998).

\section{NEUROBIOLOGY OF GABAERGIC INTERNEURONS}

Based on Golgi-impregnation studies, Ramon y Cajal provided the first descriptions of several different morphological subtypes of interneurons in the cerebral cortex and hippocampus (Ramon y Cajal 1893, 1911). In more recent years, it has been shown that, with some overlap, different morphological subtypes also have distinct distributions, connectivity, neurochemistry, and electrophysiological properties (for reviews see Hof et al. 1993; Freund and Buzsaki 1996). It is interesting to note that every segment of a pyramidal neuron, such as the soma, dendritic branches and spines, and the initial axonal segment, receives dense GABAergic synaptic innervation (O'Kusky and Colonnier 1982; Hendry et al. 1983; Houser et al. 1983; Beaulieu et al. 1992; for reviews see Jones 1993; Freund and Buzsaki 1996). Even more interestingly, each of these segments appears to be innervated by distinct GABAergic neuronal subtypes (see below).

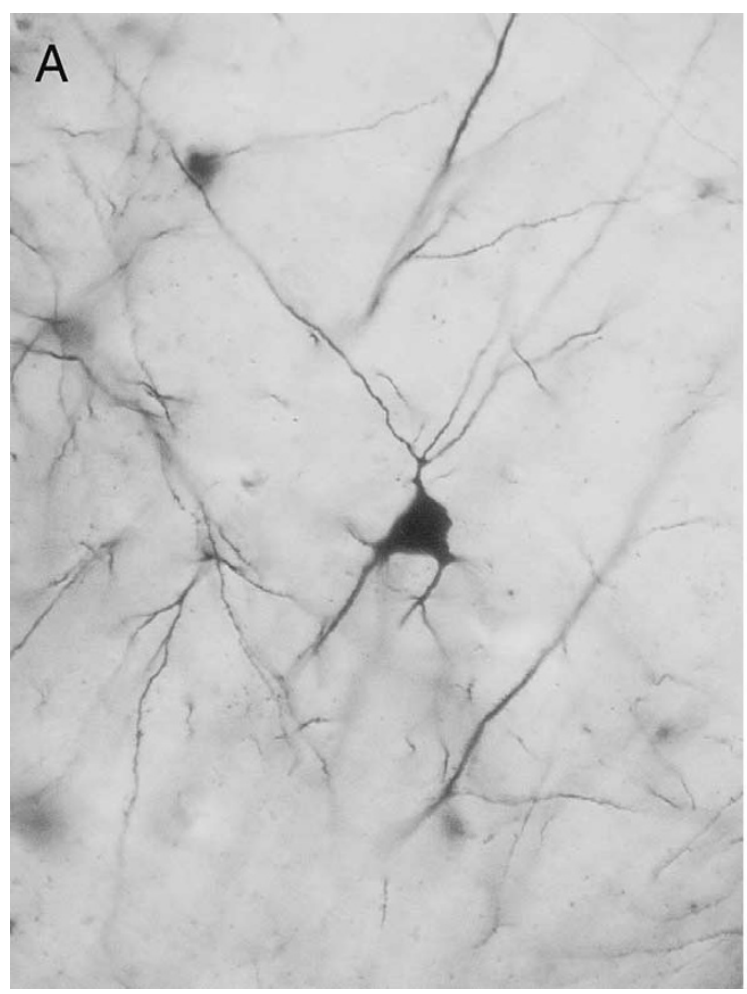

These differences strongly suggest that each of these subtypes plays a fundamentally different role in physiological and pathological mechanisms. In the discussion that follows, cortical interneurons will be described first, since our most basic understanding of GABAergic cells is derived from these populations. In more recent years, however, similar characterizations of interneurons in hippocampus have emerged. Although these cells show some striking similarities to their cortical counterparts, there are also some unique features that distinguish them. For this reason, interneurons in the hippocampus are discussed separately.

\section{Cortex}

Neuroanatomical Studies of Cortical Interneurons.

Various types of GABAergic neurons can be categorized according to the type of synaptic profiles they are associated with, as this has direct implications for understanding the physiological role of these cells in cortical circuits. These categories are discussed below.

AXo-SOMATIC INHibitory SYNAPSes (BASKet CElls). The most commonly encountered interneurons (Figure 1A) are multipolar in shape, i.e., they may have three or more primary dendritic branches emanating from their cell bodies, some having somata that are as large as those of pyramidal neurons (Jones and Hendry 1984). Using immunocytochemistry to localize the enzyme

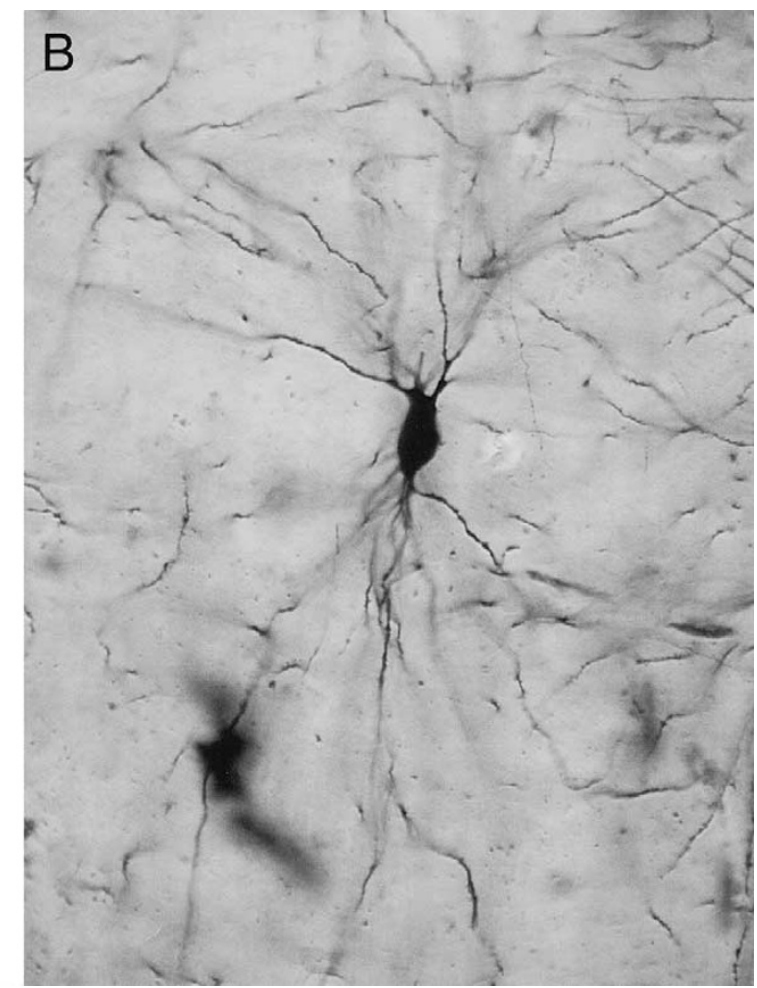

Figure 1. Nomarski photomicrographs of Golgi-impregnated neurons in human prefrontal cortex. (A). A basket cell with multipolar primary dendritic branches exiting from the cell soma. (B). A double bouquet cell that has an apical and basal set of dendritic arborizations that give the cell a somewhat bipolar appearance. 


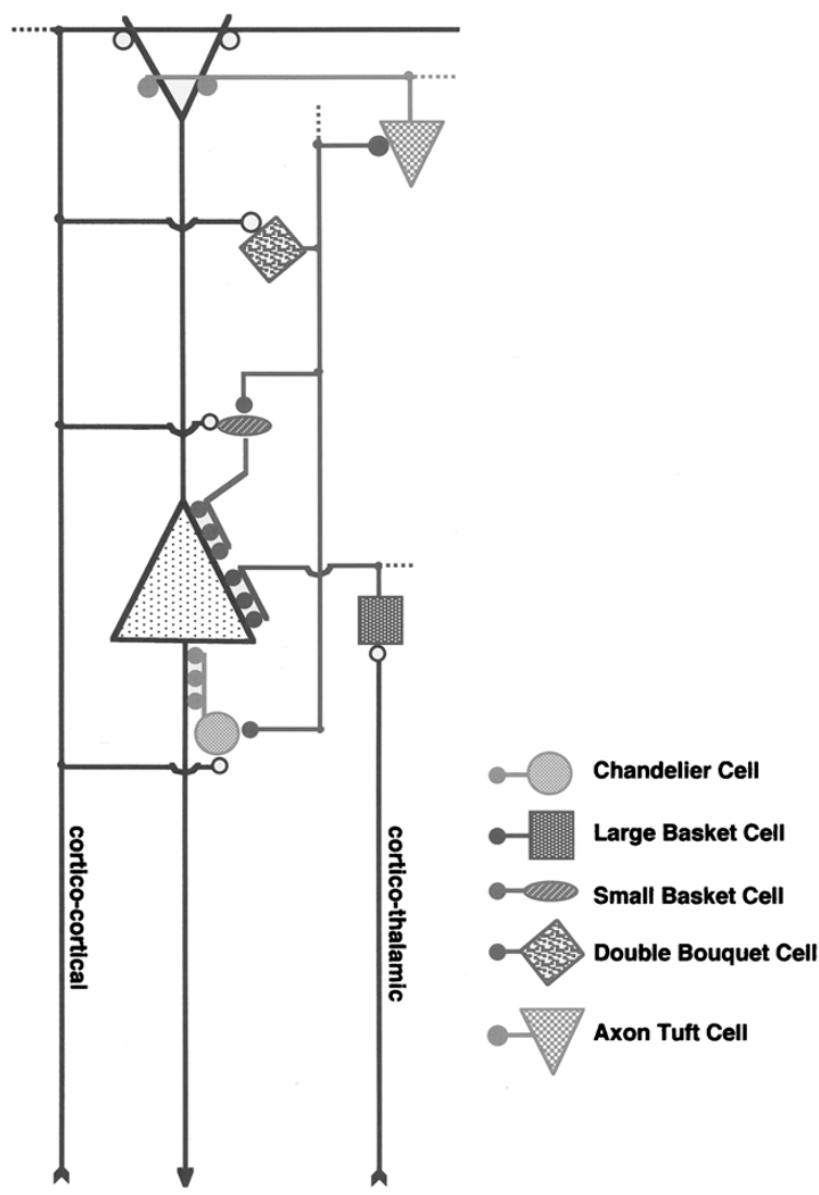

Figure 2. A schematic diagram showing the relationship between various types of GABAergic interneurons, and a pyramidal cell. Small and large basket cells, respectively, form axosomatic contacts with the cell body of the pyramidal neuron. A chandelier cell forms axo-axonic synapses with the proximal portion of the pyramidal cell dendrite. A double bouquet cell is shown forming GABA-to-GABA synapses with a small basket cell and a large basket cell and an axon tuft cell. Not shown are Cajal-Retzius neurons that are primarily found in layer I and to a lesser extent layer II of the cortex. Interneurons are depicted as receiving excitatory inputs from extrinsic afferents from other regions. (Modified from Eccles 1984.)

glutamate decarboxylase (GAD), that synthesizes GABA, the terminal boutons of basket cells have been found to form a basket-like arrangement around a large proportion of the surface of pyramidal cell bodies (Figure 2) (Hendry et al. 1983). These cells also form appositions with the proximal portions of the apical dendrites of these latter projection neurons. Because inputs at the level of the cell body exert much greater influences on the membrane potential of the cell than those located at distal points along the dendritic tree (Rall 1970), the inhibitory effect of basket cells on pyramidal cell firing is a potent one.
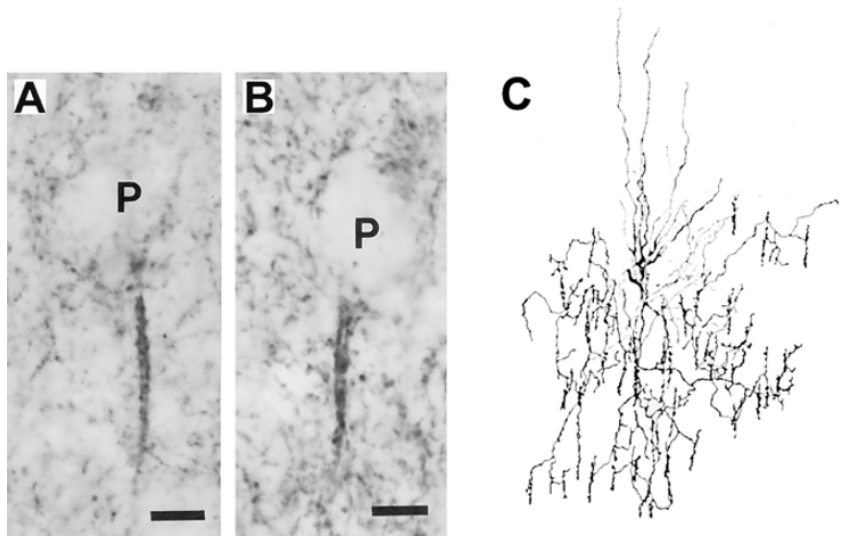

Figure 3. Light photomicrographs showing immunoreactivity for the GABA transporter (GAT-1). GAT-1 immunoreactive axon cartridges in a normal control (A) and schizophrenic patient (B) are shown to form configurations that appear like the "candles" of the chandelier neuron. (Reproduced with permission from Woo et al. 1998; Pierri et al. 1999.) (C) A reproduction of a camera lucida drawing of a Golgi-impregnated chandelier cell. Note the presence of 'candle-'like configurations that are believed to be axoaxonic connections with the initial segment of pyramidal neurons. (Reproduced with permission from Fairen et al. 1982.)

In the cortex, these neurons are abundantly present in layers III-V, but they may have very long axons that typically ascend toward more superficial laminae, become myelinated and give rise to axon collaterals that travel horizontally for distances of $900-1000 \mu \mathrm{m}$. Basket cells are, together with neurogliaform cells, the only cortical interneurons found to receive direct thalamic inputs (Figure 2) and might therefore be in the best strategic position for playing a role in shaping receptive field properties of their target neurons (Jones 1993).

AXO-AXONAL INHIBITORY SYNAPSES (CHANDELIER CELLS). These cells have axonal branches that extend at right angles from the cell body and form "candles" with a vertical orientation with respect to the surface layers (Figure 3) (Szentagothai and Arbib 1974; Peters 1984). These axonal terminations form axo-axonic synapses with the initial segment of pyramidal cell axons (Somogyi 1979). As shown in Figures 2 and 3, these socalled 'cartridges' are positioned to produce a short-circuiting of action potential propagation and thus play a major role in modulating the pyramidal neuron output activity. As shown in Figures 3A and 3B, immunolocalization of the GABA transporter (GAT-1) reveals cartridge-like structures that are believed to be the socalled "candles" of the chandelier neuron (Pierri et al. 1999; Woo et al. 1998). In the cortex, chandelier cells are predominantly found in layers II and III and are not contacted directly by thalamic afferent fibers. Thus, these neurons might be involved in modulating the 
stimulus-response properties of other neurons, rather than in shaping receptive fields as it has been postulated for basket and neurogliaform interneurons.

AXo-DendRITIC INHIBITORY AND DisINHIBITORY SYNapses (Double Bouquet Cells and Axon Tuft Cells). As shown in Figure 1B, double bouquet neurons have axonal arborizations that distribute themselves within narrow, radially oriented columns of the cortical mantle (Fairen et al. 1982). Their synaptic boutons contact mainly dendritic shafts and spines on the side branches of apical dendrites as well as on basal dendrites of pyramidal neurons (Somogyi and Cowey 1981; Somogyi et al. 1982; de Lima and Morrison 1989; DeFelipe et al. $1989 b, 1990)$. Their density is so high that double bouquet neurons are probably an important source of GABAergic synapses on pyramidal neurons in layer III.

The terminations of these interneurons have been found to form synapses with other nonpyramidal cells, some showing immunoreactivity for GAD, and it has been suggested that these may be disinhibitory elements (Somogyi and Cowey 1984). As shown in Figure 2 , double bouquet cells could potentially provide inhibitory input to both basket neurons and chandelier cells (see below). If so, the influence of this interneuronal subtype on the activity of local cortical circuits would be potentially complex and far-reaching. Like chandelier cells (see above), double bouquet cells are preferentially localized in layers II and III and are thus not reached directly by thalamo-cortical afferents; their main source of excitatory input is probably provided by cortico-cortical neurons. Axon tuft cells are small multipolar or bitufted cells which send axons in layer I where they form rich arborizations thought to synapse mainly on dendritic spines (Figure 2) (Fairen et al. 1982).

OTHER SUBTyPES OF CORTICAL INTERNEURONS. Neurogliaform cells, bipolar cells, and aspiny neurons in layer I also contact different segments of pyramidal neurons. Neurogliaform cells are of particular interest because they are, together with basket neurons, the only interneuron subtype known to be contacted directly by thalamo-cortical afferents and are thus thought to play a major role in shaping the receptive fields properties of cortical neurons (for review see Jones 1993 \#5610).

Neurochemical Markers for GABA Neurons. It has been shown in recent years that different interneuron subpopulations in the cortex, and in other brain regions such as the hippocampus (see below), can be reliably identified by their expression of neurochemical markers such as calcium binding proteins (parvalbumin, calretinin, calbindin D28k) and neuropeptides (e.g., somatostatin, cholecystokinin, neuropeptide Y). Using these markers, cortical interneurons have been characterized in detail using anatomic, biochemical and electrophysiological methods (see below). Thus, cytochemical approaches, such as immunohistochemistry or in situ hybridization, offer powerful tools for investigating neuropathological changes selectively affecting neuronal subpopulations expressing calcium binding proteins and/or neuropeptides.

Glutamate Decarboxylase (GAD). GAD is the enzyme that synthesizes GABA and this protein occurs as either a $65 \mathrm{kDalton}\left(\mathrm{GAD}_{65}\right)$ or a $67 \mathrm{kDalton}\left(\mathrm{GAD}_{67}\right)$ isoform (Kaufman et al. 1991). While $\mathrm{GAD}_{65}$ is primarily localized in axon terminals, $\mathrm{GAD}_{67}$ (Anwyl 1991) is found in the somata and dendrites of GABA cells, although some axon terminals also appear to contain this protein. A recent study has demonstrated that both isoforms are co-localized in 95\% of GABA cells in rat hippocampus; however, a small percentage of neurons may only express the $67 \mathrm{kD}$ isoform under baseline conditions (Stone et al. 1999).

PARVALBUMin (PVB). PVB has been shown to be expressed mainly by chandelier and basket cells (DeFelipe et al. 1989a; Hendry et al. 1989; Fonseca et al. 1993; Gabbott and Bacon 1996a). PVB-positive neurons in the cortex, as well as in other brain regions such as the striatum and the hippocampus, have been characterized electrophysiologically as 'fast-spiking' neurons that show: (a) repetitive firing by synaptic activation of depolarized potentials; (b) short duration action potentials with short duration after-hyperpolarizations; (c) relatively negative resting potentials; and (d) lower input resistance with respect to other neuronal subpopulations (Kawaguchi and Kubota 1995; Cauli et al. 1997). 'Fast spiking' neurons have been shown to be connected to each other both through chemical synapses as well as through electrical synapses (gap junctions) so that they have been proposed to form networks that might contribute to the synchronization of electrical activity in cortical neurons (Gibson et al. 1999).

PVB neurons also receive synaptic contacts from calretinin- (CR) positive neurons which have been found to be distributed on the soma and proximal dendrites (Gabbott and Bacon 1996a); this distribution suggests that PVB neurons might be strongly inhibited by CR neurons. PVB-positive neurons have been shown to be GABAergic and, in a small percentage, to also express calbindin D28k (CB), but not other neuropeptides (Kubota et al. 1994).

CALBINDIN D28K. This protein has been reported to be mainly expressed by double bouquet cells (Hendry et al. 1989; DeFelipe et al. 1990; Kubota et al. 1994; del Rio and DeFelipe 1995; Gabbott and Bacon 1996a) as well as by some Cajal-Retzius neurons in layer I. CB-positive neurons in the cortex were found to correspond to 'low threshold spike' cells: characterized electrophysiologically by broad spikes, pronounced adaptation of firing frequency and low-threshold spikes upon depolarization by synaptic activation (Kawaguchi and Kubota 1993, 1995). 
'Low threshold' neurons have been found to be selectively connected to each other through electrical synapses and thus proposed to play a role in generating synchronous inhibitory activity in the cortex (Gibson et al. 1999). CB-positive neurons in the cortex have also been found to be the main target of extrinsic GABAergic projections from the diagonal band of Broca (Freund and Gulyas 1991) and to receive CR-positive synaptic contacts on their distal dendrites (Gabbott and Bacon 1996a).

CALRETININ. This protein appears to be expressed by both double bouquet and bipolar cells, as well by CajalRetzius neurons in layer I and by large, otherwise nonidentified, neurons in the infragranular layers (Conde' et al. 1994; Gabbott and Bacon 1996a). From an electrophysiological point of view, CR-positive neurons have been classified as 'regular spiking' cells. Consistent with the observation that double bouquet cell synapse with other cortical interneurons (see above), CR-positive neurons have been shown to synapse with PVBand CB-positive cells (Gabbott and Bacon 1996a), suggesting that at least some subtypes of CR-cells might be disinhibitory interneurons.

Somatostatin. Somatostatin (SM)-positive neurons in the cortex have been shown to express GABA, $\mathrm{CB}$, and neuropeptide $\mathrm{Y}$, as well as nitric oxide synthase (NOS) (Kubota et al. 1994; Smiley et al. 2000). Morphologically, SM-positive neurons can be either multipolar or bitufted; some of them have been identified as Martinotti cells (Kawaguchi and Kubota 1996). Electrophysiologically, SM-positive neurons have been characterized as 'regular spiking' neurons that have been found in layers II/III and V and 'burst spiking' neurons that are exclusively localized in layer $\mathrm{V}$ (Kawaguchi and Kubota 1996). Different subgroups of SM-cells were found to also express vasoactive intestinal polypeptide (VIP) and CR.

VIP. VIP-positive neurons, have also been found to express somatostatin and parvalbumin (Kubota et al. 1994). Morphologically, VIP-positive neurons have been classified as bipolar, double bouquet, and small basket cells. These neurons showed electrophysiological characteristics typical of 'regular spiking' and 'burst spiking' neurons.

Other Classifying Principles. More recently, a detailed study of morphological, electrophysiological and synaptic (ratio of facilitation/depression of synaptic response) characteristics (Gupta et al. 2000) have lead to the development of guidelines for determining interneuronal subtypes in the cortex. According to this study, when anatomically defined neurons are classified according to their electrophysiological profile and then according to the type of synapse (see above), they form as many as fourteen distinct, non-overlapping interneuronal subpopulations! Because interneurons have been found to form synapses with functionallyrelated neurons, even ones of different subtypes, 'GABAgroups' are thought to form the most basic functional unit in the cortex (Gupta et al. 2000).

\section{Inputs to GABAergic Neurons}

INTRINSIC EXCITATORY INPUTS. The intrinsic excitatory inputs to cortical GABAergic interneurons have been shown to be intriguingly different from those to pyramidal neurons (Thomson and Deuchars 1994). Differences in postsynaptic responses have in fact been found to be due not only to diversity in postsynaptic specializations, but also to differences in presynaptic properties, indicating that the modulation of transmitter release at pyramidal neuron-interneuron synapses might be far more complex than at a pyramidal-pyramidal neuron connections (Thomson and Deuchars 1994, 1997). It is thought that the glutamatergic receptors involved in these connections are mainly nonNMDA in nature (Thomson and Deuchars 1994, 1997; Ling and Benardo 1995).

Recent work using laser scanning photostimulation has demonstrated that differences in laminar sources of excitatory input contribute significantly to the diversity of cortical inhibitory interneurons (Dantzker and Callaway 2000). For example, fast-spiking inhibitory basket cells receive strong stimulation from middle cortical layers, while slow firing ones receive their strongest input from deep laminae.

EXTRINSIC EXCITATORY INPUT. The extrinsic excitatory input to cortical neurons is mainly provided by afferents from the thalamus. It has been shown that thalamic inputs selectively contact and strongly excite 'fast spiking' interneurons, while other interneuronal subtypes such as the 'low threshold spiking' neurons receive weaker or no thalamic input (Gibson et al. 1999). 'Fast spiking' neurons have thus been proposed to be the mediators of fast, feedforward thalamocortical inhibition (Agmon and Connors 1992; Gibson et al. 1999). Interestingly, it has been shown that small changes in membrane potential and synaptic activities in thalamocortical networks, such as those occurring during shifts from states of vigilance to different phases of sleep, can drastically alter basic intrinsic neuronal properties of cortical neurons (Freund and Gulyas 1991; Steriade 1999). These findings imply that neuronal categories based on electrophysiological properties are more labile than previously thought.

INHIBITORY INPUTS. Inhibitory inputs to GABAergic interneurons can be either intrinsic, that is originate from other GABAergic neurons in the cortex, or extrinsic such as those originating from the diagonal band of Broca (Freund and Gulyas 1991) and from the zona incerta (Lin et al. 1990, 1997). GABA-to-GABA interactions in the cortex are a particularly intriguing type of connection. They have been shown to form networks 


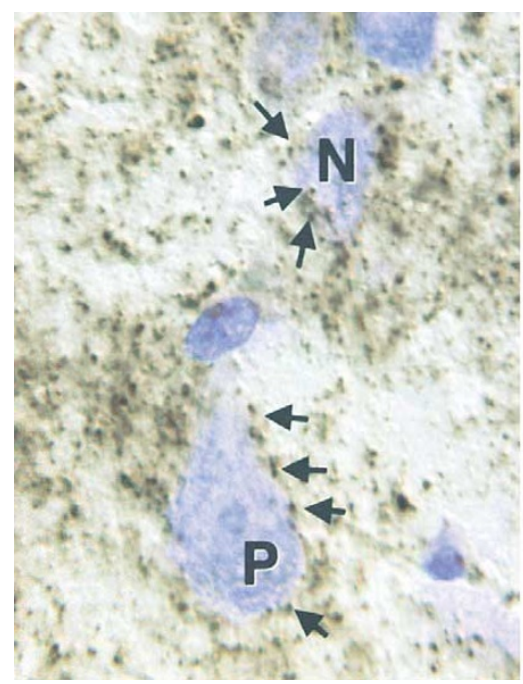

GAD-IR Terminals/ $\mu \mathrm{m}^{2}$ in Anterior Cingulate Cortex of Normal Controls and Manic Depressives

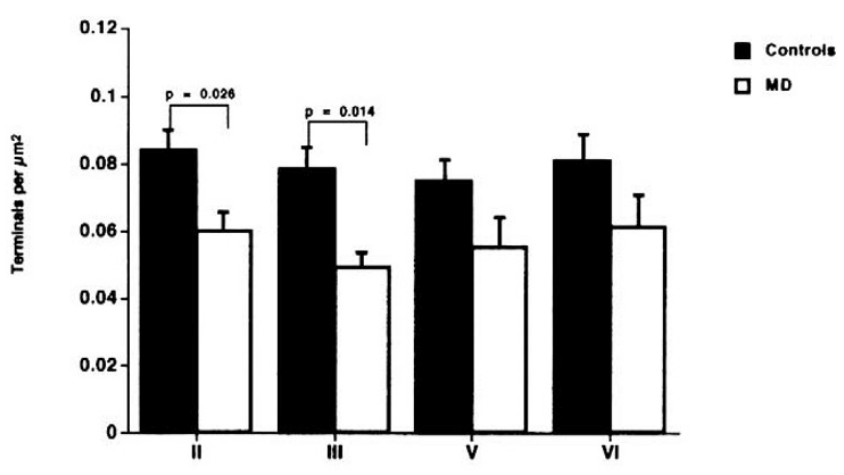

Figure 4. Light photomicrograph showing GAD-IR terminals in the anterior cingulate gyrus. Many of these terminals (arrows) can be detected around the somata of Nissl-stained pyramidal (P) and nonpyramidal (N) neurons. Densities of GAD-IR terminals around pyramidal neurons in the anterior cingulate gyrus were found to be significantly decreased in manic depressive patients as compared to normal controls (schematic diagram).

throughout the cortex in which one specific interneuronal subtype preferentially synapses with neurons of the same type (Gibson et al. 1999). As illustrated earlier these networks are connected through both GABAergic, inhibitory synapses and electrical, excitatory synapses (Gibson et al. 1999).

These networks have also been shown to be able to maintain rhythmic network activity even in the absence of excitatory inputs (Whittington et al. 1995). GABAto-GABA interactions are likely to attenuate or perhaps even shut off the activity of inhibitory neurons thus creating disinhibition downstream from the postsynaptic inhibitory interneuron (Somogyi and Cowey 1981; Kisvarday et al. 1993). However, when networks of interneurons are interconnected with one another, the final results of such complex interactions are not easily predictable by simple mathematical models (Freund and Buzsaki 1996).

MONOAMINERGIC INPUTS. Based on anatomic studies, a variety of subcortical nuclei such as the nucleus basalis of Meynert (Mesulam et al. 1983), raphe nuclei (Descarries et al. 1975; Lindvall and Bjorklund 1978), locus coeruleus (Levitt and Moore 1978), and ventral tegmental area (Thierry et al. 1973; Lindvall and Bjorklund 1984) send afferents to the cortex. These fibers employ acetylcholine, serotonin, norepinephrine, and dopamine, respectively, as neuromodulators. Some of these monoaminergic fibers seem to project directly to nonpyramidal cells of the cortex and probably influence the activity of GABAergic neurons. For example, GABA neurons in rat medial prefrontal cortex receive direct inputs from dopaminergic fibers (Goldman-Rakic et al. 1989; Verney et al. 1990; Benes et al. 1993). Consistent with this, nonpyramidal cells have been found to express both D1 and D2 receptor binding activities (Vincent et al. 1993, 1995; Davidoff and Benes 1998) or their associated messenger RNAs (Huntley et al. 1992).

More recently, using double immunocytochemistry, the two receptor subtypes have been co-localized in GABAergic interneurons, particularly those that are also positive for PVB (Le Moine and Gaspar 1998). Another study was only able to localize immunoreactivity for the D1 receptor in interneurons (Muly et al. 1998). It is important to emphasize that data obtained from cytochemical approaches, whether they be receptor binding, immunocytochemistry or in situ hybridization, are only useful when a positive localization is obtained; the absence of reaction product may only represent a failure to localize. All of these various neuromodulators can theoretically contribute significantly to the regulation of GABAergic tone in cortical neurons.

Regarding the serotonin system, a complex pattern may also exist. For example, serotoninergic fibers form contacts with interneurons and, like dopamine fibers, most do not show synaptic profiles (Smiley and Goldman-Rakic 1996). CB-/GAD-positive neurons in the cortex have been shown to be the selective target of serotoninergic terminals which tend to form 'baskets' around their somata (Hornung and Celio 1992). Consistent with this, both agonists and antagonists of serotonin receptors can be used to manipulate the activity of GABAergic neurons (Sheldon and Aghajanian 1990; Gellman and Aghajanian 1994). While both pyramidal cells and GABA neurons express the $5 \mathrm{HT}_{2 \mathrm{~A}}$ receptor subtype (Wu et al. 1998; Jakab and Goldman-Rakic 1998), the $5 \mathrm{HT}_{1 \mathrm{~A}}$ has been preferentially localized to pyramidal 
cells in the hippocampus (Gellman and Aghajanian 1994; Morilak et al. 1993), whereas the $5 \mathrm{HT}_{1 \mathrm{C}}$ receptor subtype may be preferentially found in pyramidal neurons in pyriform cortex (Sheldon and Aghajanian 1991). These observations suggest that both projection cells and local circuit cells may be potentially influenced by dopaminergic and serotoninergic projections (Gellman and Aghajanian 1993; Benes 1995). Recently, direct evidence in support of this idea has come from a triple localization demonstrating non-random contacts of tyrosine hydroxylase- (TH-) and 5HT-IR varicosities on GAD-IR neuron somata in rat medial prefrontal cortex (Taylor and Benes 1996; Benes et al. 2000).

\section{Hippocampus}

AXo-SOMATIC INHIBITORY SYNAPSES (BASKET CELLS). These neurons show characteristics very similar to those described in the cerebral cortex; however, different subtypes of hippocampal basket neurons can be distinguished on the basis of axonal arborization, location, shape and neurochemical markers (Freund and Buzsaki 1996). The common feature among these neuronal subtypes is a predominant innervation of the perisomatic regions of principal cells, so that most of their synaptic contacts cluster around the somata and the proximal portion of primary dendrites (Figure 4). Like neurons in the cerebral cortex, basket and chandelier cells in the hippocampus have been found to express PVB (Freund and Buzsaki 1996) and show a 'fast spiking' pattern (Kawaguchi et al. 1987). Interestingly, PVB-positive neurons in the hippocampus appear to be connected to each other not only through chemical synapses, but also gap junctions (Katsumaru et al. 1988). A subpopulation of basket cells which is PVB-negative, but CCK- and VIP-positive has also been identified (Gulyas et al. 1991; Acsady et al. 1996a,b).

AXO-AXONAL INHIBITORY SYNAPSES (CHANDELIER CELLS). Like their counterparts in the cortex, these neurons form axo-axonic synapses exclusively with the initial segment of the pyramidal cell axon (Kosaka 1983; Somogyi et al. 1983, 1985). Chandelier cells can be found in both the dentate gyrus and the CA subfields. In the dentate gyrus, the cell body is located within the granule cell layer and the axon arborizes profusely within the granule cell layer forming complex vertical rows of boutons that follow the granule cell axons (Soriano and Frotscher 1989; Buhl et al. 1994). In the CA subfields, the somata are found within or adjacent to the pyramidal cell layer, while their dendrites extend into the stratum radiatum, stratum lacunoso-moleculare and the stratum oriens, so that these neurons are strategically placed for receiving inputs from all major sources of afferents to the hippocampus. The axons of these interneurons form dense arborizations that follow the axons of pyramidal neurons.
AXO-DENDRITIC INHIBITORY SYNAPSES. This type of synapse is associated with neurons that are composed of numerous subpopulations, each showing great differences in the location of their somata, as well as their dendritic and axonal arborizations within the dentate gyrus and CA subfields. Most, however, almost exclusively innervate various segments of the pyramidal or granule cell dendritic tree. Each of these inhibitory cells forms multiple synaptic contacts that are distributed along various branches of a single pyramidal neuron. This distribution implies that each contact may have only a very weak effect on the postsynaptic neuron, suggesting that the activity of dendritic inhibitory cells may have to be synchronized in order to effectively modulate the membrane potential of pyramidal neurons (Freund and Buzsaki 1996; Miles et al. 1996). Another common factor is that the dendritic arborization of these neurons tends to be restricted to only one or two layers so that their influence is limited to selective intrinsic or extrinsic afferents (for a review see Freund and Buzsaki 1996). Different axo-dendritic neurons in the hippocampus have been found to selectively contain calcium binding proteins, such as $\mathrm{CB}$ and $\mathrm{CR}$, as well as neuropeptides, such as SM, NPY, and nitric oxide synthetase (NOS) (for a review see Freund and Buzsaki 1996).

INTERNEURON SELECTIVE CELLS (IS). These interneurons, which selectively synapse on other hippocampal interneurons, have been categorized according to at least three subtypes (IS-1, IS-2, and IS-3) based on their connectivity and neurochemistry (for a review see Freund and Buzsaki 1996). IS-1 neurons are CR-positive and their most salient characteristic is that they form long dendrodendritic junctions with each other that appear to connect clusters consisting of 10-15 IS-1 neurons (Freund and Buzsaki 1996). Their synaptic targets are CB-positive neurons, as well as other IS-1 cells (Acsady et al. 1996a; Gulyas et al. 1996); PVB-positive neurons do not receive afferents from IS cells. The principal inputs to these neurons is thought to be intrinsic Schafffer collaterals and extrinsic afferents from the entorhinal cortex. IS-2 neurons express VIP and contact mainly CB-positive, but not PVB-positive neurons. IS-3 neurons also express VIP and appear to selectively synapse with SM-containing neurons.

As discussed above, the simplest interpretation of interneuron-to-interneuron interactions is that activation of one GABA cell will result in the second being inhibited and its follower cell being disinhibited. Activation of complex interneuron networks, however, will probably result in a less predictable outcome.

\section{Functions of GABAergic Interneurons in the Cortex and in the Hippocampus}

Feedback and Feedforward Activity. Basic electrophysiological studies have demonstrated that the action 


\section{The Trisynaptic Pathway in Normals vs Schizophrenics}
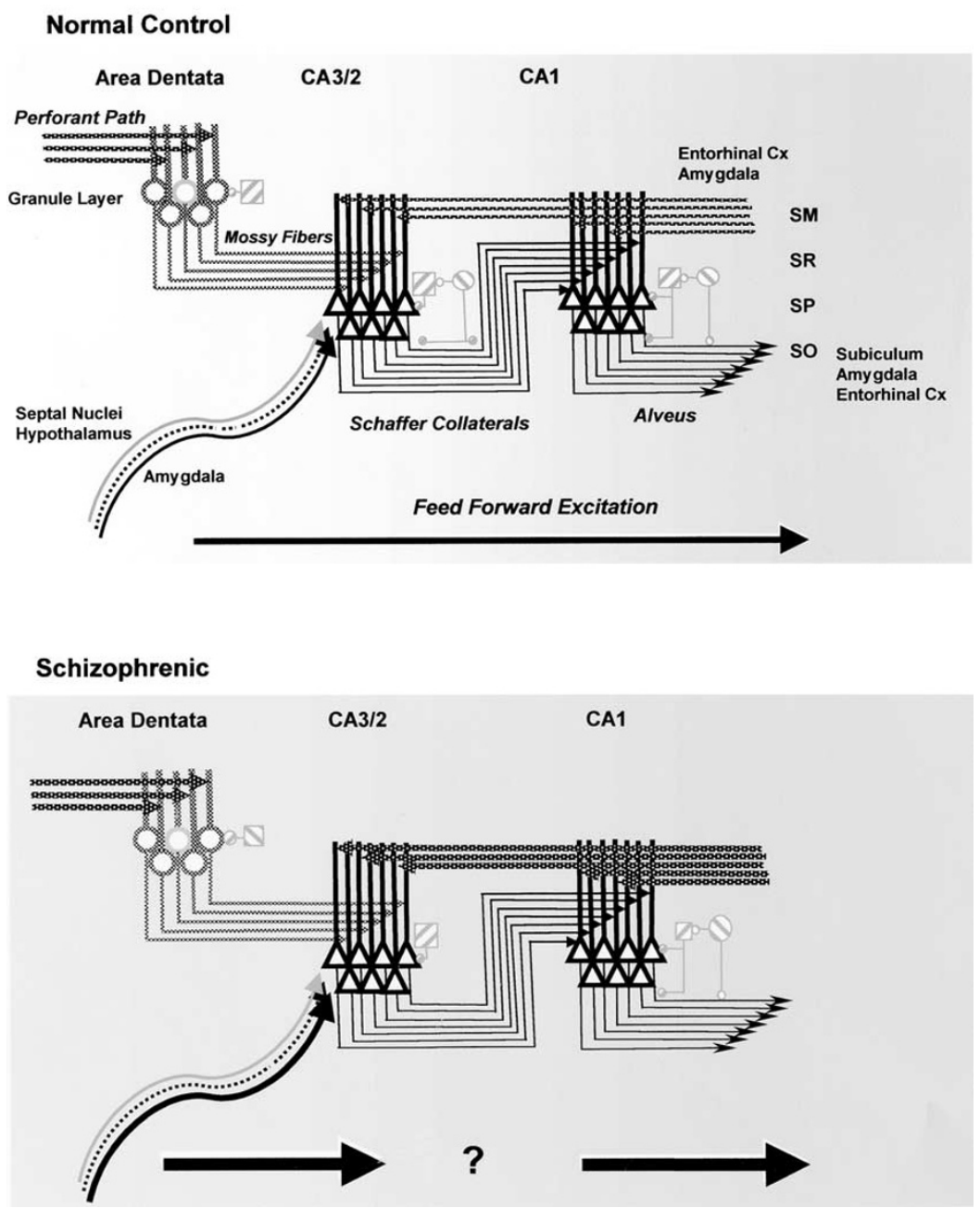

Figure 5. A schematic diagram depicting a model for conduction along the trisynaptic pathway in normal controls (upper panel) and schizophrenics (lower panel). Normal Controls: The trisynaptic pathway consists of three components: 1) perforant path fibers providing an excitatory input to the molecular layer in the area dentata; 2) mossy fibers providing an excitatory input to the stratum radiatum of CA3; and 3) Schaffer collaterals that provide an excitatory input to the stratum radiatum of CA1. The activity relayed along the trisynaptic pathway is funneled toward pyramidal cells in CA1 send which sends an efferent output to the subiculum, amygdala, and entorhinal region. The latter two regions also project back into the CA subfields along the stratum moleculare (see text for details). Sector CA3 of the hippocampus also receives direct afferents from the septal nuclei (red arrow), hypothalamus (hatched arrow) and basolateral amygdala (solid arrow). The progressive shading toward the right-hand side of the diagram indicates the direction (arrow) of a "feed forward" excitation that probably results in an amplified signal leaving sector CA1 (see text for details). There are inhibitory interneurons (square cells with hatched filling) providing GABAergic input to pyramidal cells in CA3 and CA1 and to the stratum oriens. Some GABA cells are disinhibitory interneurons (circular cells with hatched filling) that decrease the ability of the GABAergic cell to fire. Schizophrenics: A schematic diagram similar to that shown for normal controls, except that there is increased excitatory activity (thickened arrows) entering the trisynaptic pathway from three routes: 1) basolateral nucleus of the amygdala; 2) entorhinal projections to the stratum moleculare of the dentate gyrus; and 3) entorhinal projections to CA1 and CA3 from layers III and II, respectively, that travel along the stratum moleculare of the these subfields. In addition, there is a defect of GABAergic modulation at various points along the trisynaptic pathway. First, inhibitory GABAergic activity appears to be decreased in sectors CA4, CA3, and CA2, but not CA1. There is also a subtle decrease of disinhibitory modulation in the stratum pyramidale of CA3 that would result in an increased inhibition of pyramidal cell firing in this sector. Although it is difficult to understand how a dual defect in inhibitory and disinhibitory modulation in CA3 might impact on the flow of activity along the trisynaptic pathway, it seems likely that there would be an overall increase of excitatory activity along most of the trisynaptic pathway. The latter is indicated as an intensification of the dark shading occurring uniformly from the area dentata 
of GABA is typically an inhibitory one (Krnjevic 1987). It seems obvious from the above discussion, however, that different interneuronal subpopulations play different and highly specialized roles in rather complex circuits. On an elementary level of analysis, most inhibitory interneurons in the cortex and hippocampus are involved in either feedback or feedforward inhibitory mechanisms which are thought to help stabilize the activity of pyramidal neurons. In feedback inhibition, an excitatory input activates the pyramidal neuron which, in turn, excites inhibitory interneurons through recurrent collateral fibers (Andersen et al. 1964).

The inhibitory interneurons thus activated inhibit principal neurons, including those that directly excited them. Intracellular recordings from cortical pyramidal cells typically show a depolarization of brief duration that is followed by a longer lasting hyperpolarization (Sillito 1975); it is the latter component of this complex that reflects the action of GABA on the $\mathrm{GABA}_{\mathrm{A}}$-chloride ionophore complex expressed by most postsynaptic neurons (Rabow and Farb 1995). Such an arrangement provides a "fail safe" mechanism that ensures pyramidal neurons do not fire excessively. In a feedforward system, on the other hand, pyramidal neurons (e.g., in CA3) project downstream to other pyramidal cells in CA1 (refer to Figure 5, upper panel). In addition, however, these excitatory neurons also project to interneurons of CA1, and this ultimately curtails the excitability of pyramidal neurons in this latter sector (Buzsaki 1984).

Network Oscillations. In both the cortex and the hippocampus, complex interconnections between GABAergic interneurons and pyramidal cells have been found to establish and maintain large scale network oscillations, such as those in the theta, gamma $(40-100 \mathrm{~Hz})$, and ultrafast $(200 \mathrm{~Hz})$ frequency ranges (Buzsaki and Eidelberg 1983; Fraser and MacVicar 1991; Buzsaki et al. 1992; Soltesz and Deschenes 1993; Amzica and Steriade 1995; Bragin et al. 1995; Buzsaki and Chrobak 1995; Whittington et al. 1995; Ylinen et al. 1995a,b; Freund and Buzsaki, 1996; Jefferys et al. 1996; Buzsaki 1997).

As shown in Figure 6, studies of theta oscillations have demonstrated that both interneurons and pyramidal cells fire during the negative phase of the waveform; however, the interneurons discharge earlier than pyramidal cells. In the cortex, networks of inhibitory in-

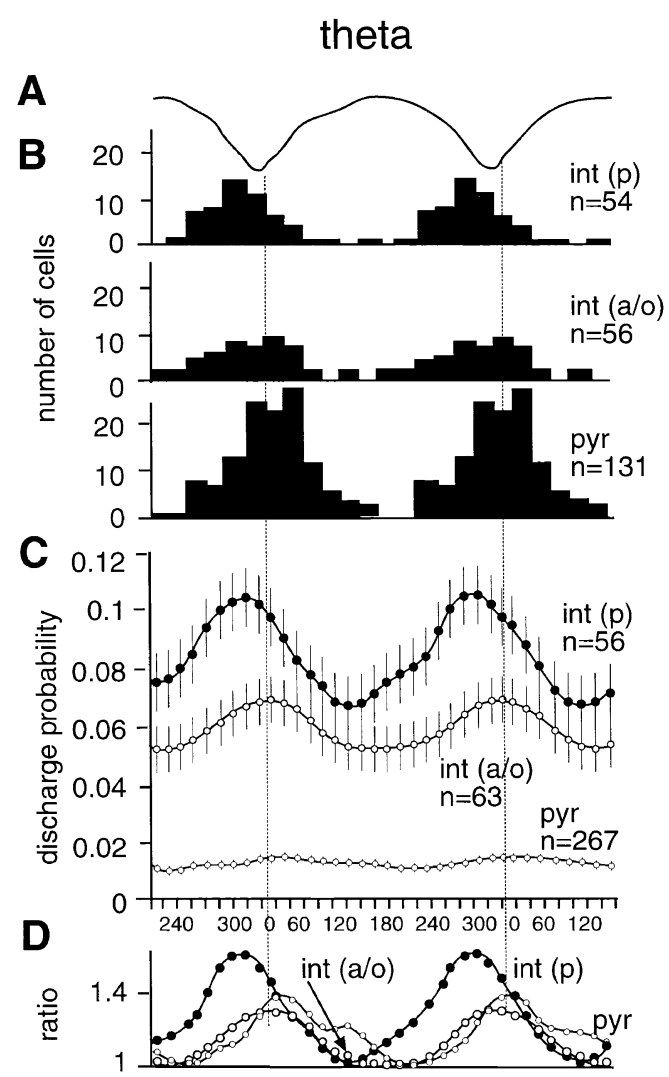

Figure 6. Two theta wave cycles are shown (A) together with phase distributions of interneurons in the stratum pyramidale, int(p), and stratum oriens/alveus, int(a/o), as well as pyramidal cells (pyr) with significant phase modulation (B). Both interneurons and pyramidal cells fire during the negative phase of the theta wave, but were much less likely to fire during the positive phase $(\mathbf{C})$. The int(p) and $\operatorname{int}(\mathrm{a} / \mathrm{o})$ interneurons discharged earlier than the population peak activity of the pyramidal neurons. (Reproduced with permission from Csicsvari et al. 1999.)

terneurons have been found to entrain pyramidal cell discharges. This results in coherent oscillations that have been proposed to 'group' or 'bind' features detected in different cortical areas into a unified perceived object (Whittington et al. 1995). In the hippocampus, these oscillations have been proposed to provide the "context" for the "content" coded by excitatory projection neurons (for review see Buzsaki and Chrobak 1995; Buzsaki 1997). According to this hypothesis, GABAer-

through sector CA1. In the area dentata, the feed forward excitatory drive progressively increases as the conduction of impulses passes toward CA1. Since the changes in GABAergic integration in CA3 are complex and the increase of disinhibitory activity may have the ability to offset some of this excitation potentially offsetting, the arrow is missing in this sector and is replaced by a question mark (?). In CA1, the excitatory drive would attains its highest level of activity, particularly since a decrease of inhibitory modulation appears to be minimally present in this sector in schizophrenics. Taken together, these hypothesized changes would be capable of generating an overall increase of basal metabolism in this region, but an impaired ability to selectively retrieve information when challenged with a specific task (Adapted with permission from Benes and Berretta) (Benes and Berretta 2000a). 
gic 'supernetworks' may control pyramidal neurons and provide the temporal structure needed to coordinate and maintain the function of neuronal ensembles in the hippocampus. The available evidence suggests that networks of hippocampal interneurons are capable of generating gamma frequency oscillations (Traub et al. 1997). For the theta rhythm, basket cells have been found to have regular membrane oscillations and the occurrence of rhythmic inhibitory postsynaptic potentials are believed to involve GABAergic inputs from the septal nuclei (Ylinen et al. 1995a). Thus, GABA-to-GABA interactions, even ones involving extrinsic afferents, seem to play a key role in the generation of rhythmic activity by the hippocampus.

Discriminative Processing. Growing evidence supports the hypothesis that cortical interneurons can influence the discriminative responses of pyramidal neurons. For example, in the visual system, GABAergic interneurons play a key role in modulating the activity of geniculate inputs to the primary visual cortex and defining the orientation selectivity of its neurons (Sillito 1975, 1984; Tsumoto et al. 1979). Support for a role of interneurons in shaping of receptor fields has been extended to other cortical areas such as the somatosensory cortex (Alloway et al. 1989; Alloway and Burton 1991; Wilson et al. 1994; Kyriazi et al. 1996). For instance, recordings from layer IV barrel neurons of the somatosensory cortex in the presence of GABA receptor antagonists indicates that inhibitory receptive field properties of barrel neurons can be explained by intrabarrel inhibition and that the expansion of receptive field size during GABA blockade is due to an enhanced effectiveness of convergent, multiwhisker thalamocortical inputs (Kyriazi et al. 1996).

Interestingly, in monkey prefrontal cortex, interneurons have receptive fields similar to those found for pyramidal neurons. This suggests that interneurons carry a specific informational signal (Wilson et al. 1994). In these experiments, the timing of excitatory and inhibitory responses appeared to be phased, a property consistent with a role of interneurons in shaping receptive fields. Furthermore, it has been shown that, in the motor cortex, intrinsic inhibitory circuits maintain and adapt motor representations (Jacobs and Donoghue 1991). Inhibitory interneurons appear to be able to unmask latent connections, so that rather than being static, somatotopic maps can continually reorganize (Jacobs and Donoghue 1991). It can readily be appreciated that similar neurons located in associative cortical regions may help to define the nature and integrity of higher cognitive functions, such as motivation, attention, learning and object recognition. For example, recent findings suggest a role for cortical interneurons in working memory (Wilson et al. 1994; Rao et al. 1999, 2000). In the dorsal prefrontal cortex, 'fast spiking' interneurons have been shown to play an important role in shaping 'spatial memory fields' much in the same way as they have been found to shape 'sensory receptive fields' (Rao et al. 1999, 2000). In addition, blockade of GABAergic inhibition in the inferotemporal area has been associated with a disruption of the normal response of neurons selective for particular object features (Wang et al. 2000).

Long-Term Potentiation and Depression. Intrinsic inhibitory interneurons in the hippocampus may also control long-term modifications of synaptic strength induced by synaptic transmission (Buzsaki et al. 1996; Maccaferri and McBain 1996; Miles et al. 1996; Tsubokawa and Ross 1996; McMahon and Kauer 1997; Laezza et al. 1999).

Phenotypical Differentiation. Finally, and of interest for the field of schizophrenia research, hippocampal interneurons have been shown to regulate the differentiation of hippocampal neurons during development (Marty et al. 1996). That many of these functions might involve functional (and presumably structural) neuroplasticity is strongly suggested by the observation that GABA, GAD, and the $\mathrm{GABA}_{\mathrm{A}}$ receptors are all regulated in an activitydependent manner (Jones 1990, 1993). This raises the question as to whether phenotypic changes in the GABA system seen in schizophrenia and bipolar disorder might be related to increases or decreases in the flow of afferent activity into the cortex and hippocampus from other regions with which they are connected (see below).

\section{THE GABA SYSTEM IN SCHIZOPHRENIA}

GABA dysfunction is believed to play a role in various neuropsychiatric disorders. For example, as early as 1972, Eugene Roberts postulated that this compound might play a central role in the pathophysiology of schizophrenia (Roberts 1972). Schizophrenia typically involves disturbances of cognitive functioning that include impaired attentional responses (McGhie and Chapman 1961), disruptions of normal information processing (Saccuzzo and Braff 1986; Braff et al. 1991), and a selective impairment in declarative memory (Heckers et al. 1998). Overall, the thought pattern of schizophrenics has been described as being "over-inclusive", i.e. there is an inability to filter out extraneous information (Cameron 1938; Payne et al. 1961; Payne and Friedlander 1962). This has lead to the speculation that an impaired central filtering mechanism may be present in this disorder (Detre and Jarecki 1971), as schizophrenics are unable to distinguish relevant objects in the perceptual field (Matussek 1951).

Using physiological recordings from schizophrenics, a decreased auditory-evoked P50 response to repeated stimuli has been noted (Adler et al. 1982). These authors concluded that such a defect may be related not only to sensory gating difficulties, but also to problems with 


\section{A ANTERIOR CINGULATE GYRUS}

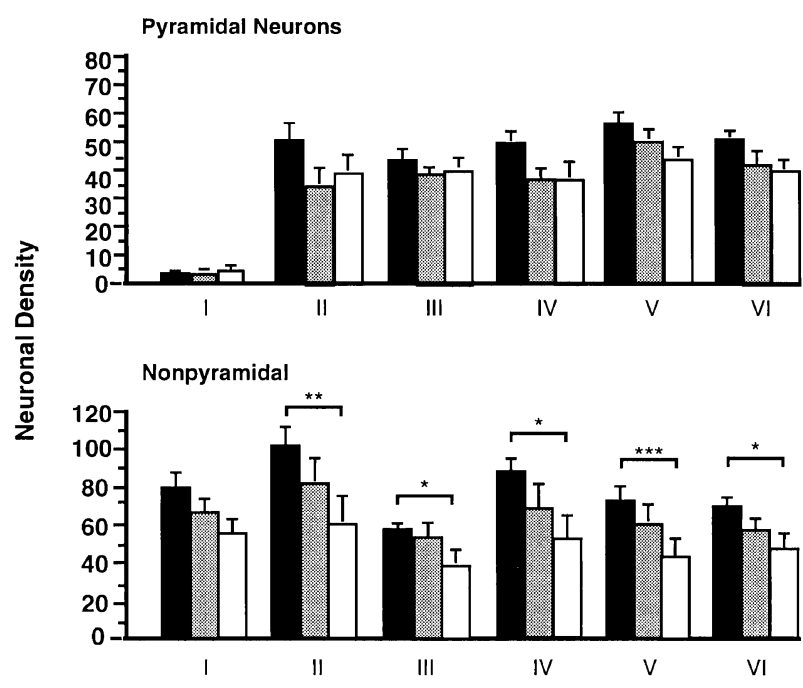

B

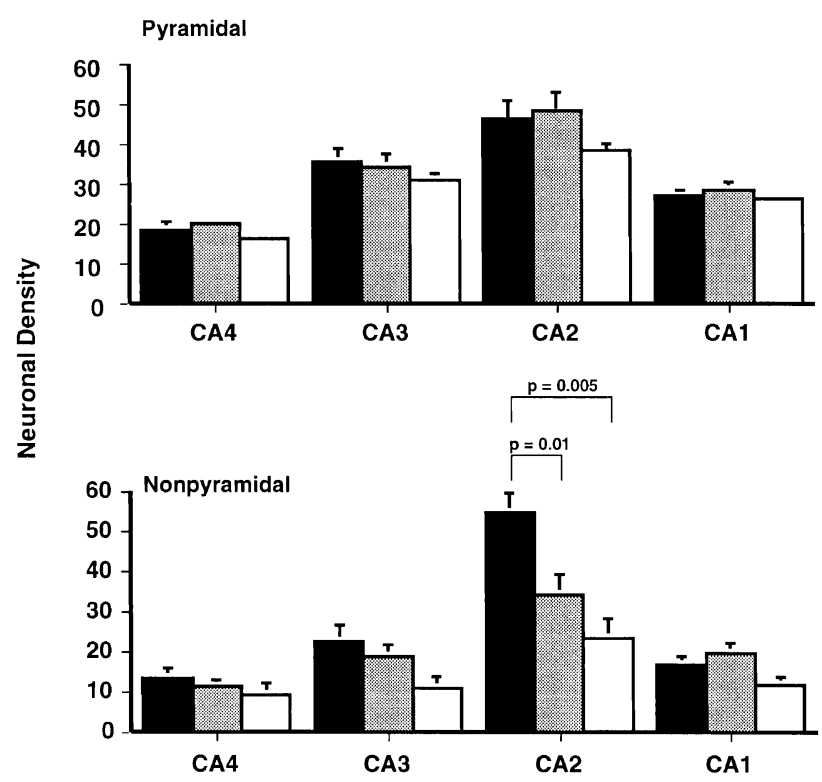

Figure 7. (A). In the anterior cingulate cortex the density of pyramidal and nonpyramidal neurons of normal controls (solid bar), schizophrenics (hatched bar) and schizoaffective (open bar) subjects. Pyramidal neurons do not show significant differences among the groups, while nonpyramidal cells are decreased in layers II, III, V, and VI of the schizophrenics and schizoaffectives, particularly the latter where the differences are significant. (Reproduced from Benes et al. 1991.) (B). In the hippocampus, the average number of pyramidal neurons also showed no significant differences between the normal controls (solid bars), schizophrenics (hatched bar) and manic depressive patients (open bars) in any of the sectors examined. However, nonpyramidal neurons showed a significant reduction in the average number in learning efficiency and accuracy. The most consistent electrophysiological abnormality observed in schizophrenia, however, is a reduced amplitude and increased latency of the P300 evoked potential (Blackwood et al. 1991). These changes are related to a diminished ability to habituate selective attentional responses to a stimulus and could reflect defective GABAergic inhibitory modulation. Consistent with this idea, a recent PET study has demonstrated an increase of basal metabolism in the hippocampal formation of schizophrenic subjects (Heckers et al. 1998) and, as shown in Fig. 5, this finding is consistent with a recent model for how the GABA system in this region may be dysfunctional in schizophrenia (Benes 1999; Benes and Berretta $2000 \mathrm{~b})$. On a highly speculative level, it could be hypothesized that decreased GABAergic transmission in specific cortical areas could result in rearrangement, and possibly enlargement, of sensory, memory and 'cognitive' fields and thereby lead to overinclusive, disorganized thought processes.

In order to better understand the functional implications of a dysfunction of the GABA system in schizophrenia, it is necessary to have direct empiric evidence demonstrating alterations of specific markers for this neurotransmitter system. To date, such information has come largely from postmortem investigations as discussed below.

\section{Postmortem Evidence for a GABA Defect in Schizophrenia}

\section{Numerical Density of Interneurons.}

Cell Counting Studies. Cerebral cortex: In 1991, a postmortem study in which pyramidal and nonpyramidal neurons were differentially counted in cresyl violetstained sections revealed a decreased density of nonpyramidal cells in layers II-VI of the anterior cingulate area and layer II only of the prefrontal cortex of schizophrenic and schizoaffective subjects (Benes et al. 1991). In the anterior cingulate cortex (Figure 7A), however, these changes were primarily significant in the schizoaffective group, suggesting the possibility that they might show a stronger covariation with affective disorder than with schizophrenia. Nevertheless, this finding is controversial since several other groups have not demonstrated a similar change in the prefrontal cortex of schizophrenics (Selemon et al. 1995, 1998; Akbarian et al. 1995; Arnold et al. 1995) and the anterior cingulate cortex of bipolar subjects (Ongur et al. 1998).

There are significant methodologic factors that may have contributed to these failures to replicate the reduced density of nonpyramidal cells. Not least among

sector $\mathrm{CA}_{2}$ but only a trend in sector $\mathrm{CA}_{3}(p=.067$ and $p=$ .065 , respectively). (Reproduced from Benes et al. 1998.) 
these are the difficulties in comparing data obtained with two dimensional cell counting methods with those obtained with three dimensional techniques. Both have their strengths and weaknesses, although the precision of the 3D optical disector method has been seriously challenged (Benes and Lange 2000). Specifically, with the optical disector method, the size of the window used to count cells in the $\mathrm{x} / \mathrm{y}$-plane is very small, while that used with 2D approaches is almost 35-fold larger. This increase of window size provides estimates that take into account the fact that neurons are not distributed in a random or Poisson fashion and marked variations in the size, shape and numerical density of neurons occur within different layers and sublaminae.

Of equal concern is the fact that optical disector counting incurs a marked degree of collapse in the $z$-axis and this differentially effects the numerical density of neurons, such that the numbers of larger pyramidal neurons would tend to be over-estimated when compared to the smaller nonpyramidal neurons. In contrast, two dimensional counting approaches typically use relatively thin sections (e.g., $20 \mu \mathrm{m}$ ) that collapse to approximately 5-6 $\mu \mathrm{m}$ in thickness when mounted on glass slides. This latter thickness is similar to the depth of focus of a 25X objective lens, making it routinely possible to count all of the cells within the original $20 \mu \mathrm{m}$ thickness of the section, without the effect of $\mathrm{z}$-axis collapse in this plane. Overall, it is important to consider the type of cell counting method employed in evaluating the differences in findings that have been reported in schizophrenia.

In a subsequent replication study, a 2D method was employed to study a cohort in which both schizophrenics and manic depressives were included as comparison groups. The results of this study showed a pattern similar to that previously reported (Benes and Lange 2001). The manic depressives showed approximately a 30\% decrease, whereas the schizophrenics showed a $16 \%$ decrease. It is noteworthy that another study in which tyrosine hydroxylase-immunoreactive fibers were analyzed (Benes et al. 1997a) found in a post hoc analysis an $18 \%$ reduction in the density of nonpyramidal neurons in layer II of ACCx in schizophrenics (Benes 1998). More recently, the findings from these three studies have been combined and a meta-analysis performed. The data indicate that the reduction in the density of nonpyramidal neurons in layer II of ACCx was $16 \%$ in the schizophrenics $(n=25), 25 \%$ in schizoaffectives $(n=18)$, and $30 \%$ in manic depressives (Benes and Todtenkopf 1998). Taken together, these data suggest that a loss of interneurons does occur in affective disorder as well as schizophrenia.

Hippocampus: In a recent study of the hippocampal formation (Figure 7B), a preferential decrease in the number of nonpyramidal neurons was observed in sector CA2; however, in this region, the change occurred to an equivalent degree in both schizophrenics and manic depressives (Benes et al. 1998; Benes and Todtenkopf 1998). Based on these results, it has been postulated that a loss of GABAergic neurons might be related to a factor, such as stress, that both disorders would share to an equivalent degree. It is not straightforward to explain why there is a greater decrease in the density of nonpyramidal neurons in manic depressives, than in schizophrenics. Nor is it obvious why this parameter shows an equivalent change in the hippocampal formation of both disorders; however, it is conceivable that each disorder may involve region-specific alterations of neural circuitry that impact on GABAergic neurons to differing degrees, depending upon the specific diagnostic category.

Calcium Binding Peptides. Cerebral Cortex: As discussed above, variety of peptides have been found to be associated with various subtypes of nonpyramidal neurons and are being used to identify specific phenotypes of GABAergic inteneurons (Conde' et al. 1994). An ICC localization of the calcium binding protein parvalbumin has demonstrated a decrease of cells showing this immunoreactivity in the prefrontal cortex of schizophrenics (Beasley and Reynolds 1997).

In another study, however, prefrontal areas 9 and 46 showed no differences in the distribution of neurons expressing detectable levels of PVB-IR (Woo et al. 1997). In the anterior cingulate cortex, on the other hand, an increase of cells immunoreactive for this peptide has been reported in schizophrenics (Kalus et al. 1997). In attempting to interpret such disparate results, it is important to consider whether differences in the regions studied, tissue handling and perhaps even subject populations may account for the discrepancies. All of these factors may potentially influence whether the amount of PVB-IR is either above or below the level of detection.

For $\mathrm{CB}$, an increase in the numerical density of neurons showing immunoreactivity for this peptide in the dorsolateral prefrontal cortex was observed, whereas there was no change in those containing CR-IR (Daviss and Lewis 1995). Unfortunately, there have not as yet been another studies reporting on this peptide in the prefrontal cortex of schizophrenics.

Hippocampus: $\mathrm{CB}$ expression has been shown to be decreased (Takahashi et al. 2000) and CB-IR neurons have been reported to show a marked degree of disarray, particularly evident in sector CA2 (Iritani et al. 1999). Although an overt decrease in the numerical density of these cells was not detected, this study is noteworthy because, as noted above, a selective loss of nonpyramidal neurons has been found in sector CA2 of subjects with schizophrenia and bipolar disorder (Benes et al. 1998).

Taking together the results of cell counting studies using cresyl violet-stained sections with those immunocytochemically localizing antibodies against various 
calcium binding proteins, there does not appear to be a definitive answer as to whether a decrease of interneurons is present in the cortex and hippocampus of schizophrenic subjects. On the one hand, studies of cresyl violet stained sections suffer from significant issues regarding cell counting methodology. On the other hand, studies that have localized PVB, CB, and CR are impeded by the factors that influence the retention of immunoreactivity in the tissue and the fact that increases or decreases of detectable levels of peptide may occur without any overt change in the actual number of neurons. Thus, the apparent changes in numerical density of such cells can be quite misleading.

Markers for GABAergic Terminals. In the 1970s, perhaps prompted by the speculations of Eugene Roberts (Roberts 1972), a series of neurochemical investigations focusing on various markers for this system were reported. The first study to appear examined the concentrations of GABA in the nucleus accumbens and thalamus of patients with schizophrenia and compared them with a group of subjects with Huntington's chorea (Perry et al. 1979). The results demonstrated a reduction of this transmitter that was equivalent in the two disorders. Contemporaneously, another study reported that the activity of GAD was significantly reduced in schizophrenics (Bird et al. 1977). Although it began to appear that a pattern of decreased GABAergic activity was emerging, subsequent studies failed to show changes in either GABA levels or GAD activity (Cross et al. 1979), even though one study did show a non-significant decrease of GAD in the prefrontal cortex (Hanada et al. 1987). Because subjects who died suddenly were less apt to show such changes, it appeared that decreases in the specific activity of GAD might be related to the agonal state and might have been confounded in these studies (Bird 1977, \#2626).

More consistent findings have come from studies of the GABA uptake site where reductions of this marker have been consistently observed in prefrontal cortex (Simpson et al. 1989), amygdala (Reynolds 1983), and hippocampus (Reynolds et al. 1990) of schizophrenic brain. A recent attempt to replicate this finding in prefrontal and temporal cortex, however, did not show any differences in schizophrenics (Simpson et al. 1998).

More recently, the $65 \mathrm{kDalton}$ isoform of GAD, a marker for GABAergic terminals (Kaufman et al. 1991), has been localized immunocytochemically in the anterior cingulate cortex, where schizophrenic patients showed no differences (not shown) while, in bipolar subjects, a marked decrease was detected on pyramidal neurons in layers II and III (Figure 4). In the hippocampal formation, no overall differences between normal controls and schizophrenics were detected in the density of $\mathrm{GAD}_{65}$-IR terminals on either pyramidal or nonpyramidal cells in any of the subregions or sublaminae
(Todtenkopf and Benes 1998). However, a small number of subjects who were neuroleptic free for at least a year prior to death showed a significant reduction on both neuronal subtypes in sectors CA4, CA3, and CA2, but not CA1. The subjects treated with neuroleptics showed a dose-related increase in terminal density in these sectors, particularly in the stratum oriens of CA3 and CA2. These data suggest that there may be an intrinsic reduction of GABAergic terminals in the hippocampus of schizophrenics and the therapeutic efficacy of the neuroleptic drugs may involve, at least in part, a trophic sprouting of these terminals. This conclusion is consistent with a controlled study in rat medial prefrontal cortex (anterior cingulate region) in which chronic haloperidol administration was associated with a marked increase of GABA-IR terminals (Vincent et al. 1994b).

Whether such changes require blockade of dopamine receptors on GABA cells is not clear; however, the increase in this latter study were most striking in layer II where the dopaminergic projections to this region are most sparse (Lindvall and Bjorklund 1984). Thus, antipsychotic drugs may be capable of inducing changes in GABA cells that are mediated either alone or in combination with other mechanism, such as the $5 \mathrm{HT}_{2 \mathrm{~A}}$ receptor (Benes 1995) or possibly even direct trophic changes in synapses (Benes et al. 1983, 1985; Kerns et al. 1992).

Other cytochemical studies have employed in situ hybridization (ISH) to examine the distribution of mRNA for GAD, particularly that for the 67 kDalton isoform $\left(\mathrm{GAD}_{67}\right)$ (Kaufman et al. 1991). In the prefrontal cortex of schizophrenics, a reduction in the number of cells expressing $\mathrm{GAD}_{67}$ mRNA has been reported by two different groups (Akbarian et al. 1995; Volk et al. 2000).

More recently, a decrease in $\mathrm{GAD}_{67} \mathrm{mRNA}$, but not $\mathrm{GAD}_{65}$, expression has again been noted (Guidotti et al. 2000). A variety of studies have suggested that $G_{A D}$ is regulated through transcriptional mechanism. For example, increased expression of mRNA for this protein has been found in relation to lesioning of the substantia nigra (Vernier et al. 1988; O'Connor et al. 1991), climbing fibers of the cerebellum (Litwak et al. 1990) and in the hippocampus in response to systemic treatment with kainic acid $\mathrm{GAD}_{67}$ (Feldblum et al. 1990). In contrast, expression of mRNA for $\mathrm{GAD}_{65}$ has been found to be relatively stable (Ding et al. 1998; Feldblum et al. 1998). Similarly, expression of $\mathrm{GAD}_{65}$ protein also appears to be relatively stable (Martin et al. 1993) and appears to be controlled primarily through post-translational mechanisms (Miller et al. 1991).

The postmortem findings obtained with either immunocytochemistry or ISH showing decreased expression of $\mathrm{GAD}_{67}$, but not $\mathrm{GAD}_{65}$, as well as stable levels of immunoreactivity for $\mathrm{GAD}_{65}$ in terminals of the hippocampal formation (Todtenkopf and Benes 1998) are consistent with these ideas. Since mRNA for the two isoforms of GAD are expressed by $95 \%$ of the neurons 
in rat hippocampus (Stone et al. 1999), it seems likely that complex cellular mechanisms may be influencing the nature of the results observed in these postmortem studies. The fact that changes in $\mathrm{GAD}_{67}$ mRNA have been observed not only in schizophrenics, but also in subjects with bipolar disorder (Guidotti et al. 2000; Heckers et al. 2001) suggests that these changes may be related to a nonspecific factor associated with both disorders. Interestingly, differential expression of mRNAs associated with the two isoforms of GAD have been reported in relation to both acute and chronic stress (Bowers et al. 1998), although in this case that for $\mathrm{GAD}_{67}$ was increased, rather than decreased as it is in schizophrenia and bipolar disorder.

A recent study in rats has attempted to model for the effects of pre- and/or postnatal stress by injecting rats with corticosterone (Stone et al. 2001). Within $24 \mathrm{hrs}$ of the last injection, a decreases of mRNA for $\mathrm{GAD}_{67}$, but not $\mathrm{GAD}_{65}$, was observed in the dentate gyrus, CA4, CA2, and CA1 of rats exposed both pre- and postnatally. Five days after the last injection, however, the levels of mRNA for $\mathrm{GAD}_{67}$ returned to normal, while those for $\mathrm{GAD}_{65}$ were markedly increased.

Another finding supporting the presence of disruption of GABAergic networks in schizophrenia, is the decrease of 'cartridges' immunopositive for the GABA membrane transporter (GAT-1) in prefrontal cortex (Figures 3A and 3B) (Woo et al. 1998; Pierri et al. 1999). As discussed above, these 'cartridges' represent axo-axonic terminations of chandelier neurons and are strategically positioned within cortical circuitry to modulate cortical output. Thus, their decrease is likely to reflect crucial changes in information processing in the cortex. Other terminals with a more conventional punctate structure did not show differences, thus suggesting selectivity to a population of GABA terminals that accounts for only $1 \%$ of the total. It is not known, however, whether GAT1 containing terminations express $\mathrm{GAD}_{65}$ and/or $\mathrm{GAD}_{67}$.

GABA Receptor Binding Activity. The GABA agonist binding of $\left[{ }^{3} \mathrm{H}\right]$ muscimol, was evaluated in the prefrontal cortex of controls and schizophrenics matched for age, but with an average postmortem interval of 8 and $13 \mathrm{hrs}$, respectively (Hanada et al. 1987). The data indicated that the schizophrenics showed a $48 \%$ increase in the $B_{\max }$, but no difference in affinity for $\left[{ }^{3} \mathrm{H}\right]$ muscimol binding. Addition of the benzodiazepine, diazepam, resulted in a greater increase in binding in the schizophrenics. One limitation of this study was the fact that GABA was used as a competitive inhibitor, rather than bicuculline, a specific antagonist of the $\mathrm{GABA}_{\mathrm{A}}$ receptor (Rabow and Farb 1995), making it unclear as to whether the results reflect changes in this latter receptor or possibly the $\mathrm{GABA}_{\mathrm{B}}$ receptor and, perhaps, even the GABA transporter.
Subsequent investigations have specifically investigated high affinity binding to the $\mathrm{GABA}_{\mathrm{A}}$ receptor complex. Using bicuculline as a selective antagonist, $\left[{ }^{3} \mathrm{H}\right]$ muscimol binding was found to be increased in the hippocampal formation (Figure 8) (Benes et al. 1996b), anterior cingulate cortex (Benes et al. 1992) and prefrontal region (Figure 9) (Benes et al. 1996b; Dean et al. 1999), of schizophrenic subjects. It is noteworthy, however, that benzodiazepine receptor activity did not show differences in the hippocampal formation (Figure 8), suggesting that there might be an uncoupling in the regulation of these two sites on the $\mathrm{GABA}_{\mathrm{A}}$ chloride ionophore complex (Benes et al. 1997b). One other study had reported a decrease of benzodiazepine receptor binding in the cortex (Squires et al. 1993), but it is not clear if the subjects in this study were treated with benzodiazepine agents prior to death. It is also important to note that this pattern does not preclude the presence of an allosteric uncoupling in the regulation of the receptor.

SPECT imaging investigations have also attempted to study the $\mathrm{GABA}_{\mathrm{A}}$ receptor in schizophrenia using specific ligands, such $\left[{ }^{123} \mathrm{I}\right]$ iomazenil for the benzodiazepine receptor. While two such studies have found no differences in schizophrenics (Busatto et al. 1997; AbiDargham et al. 1999), two others have found a reduction in this binding activity (Verhoeff et al. 1999; Ball et al. 1998). In two of these studies, changes in the benzodiazepine receptor correlated with cognitive impairment (Ball et al. 1998) or severity of illness (Busatto et al. 1997). It is important to emphasize that these studies were probably examining only the benzodiazepine site on the $\mathrm{GABA}_{\mathrm{A}}$ chloride ionophore complex so that, in the setting of an allosteric uncoupling in its regulation, the status of the $\mathrm{GABA}_{\mathrm{A}}$ site cannot be inferred from such imaging data.

A high resolution microscopic technique has provided specific information regarding the distribution of this receptor binding activity on pyramidal neurons versus nonpyramidal cells (interneurons). In the prefrontal (Benes et al. 1996c) and anterior cingulate (Benes et al. 1992) cortices, increases $\mathrm{GABA}_{\mathrm{A}}$ receptor binding activity has been preferentially found on pyramidal, but not nonpyramidal neurons, particularly in layer II where the effect size was largest (Figure 9). This pattern was thought to be consistent with the hypothesis that a compensatory upregulation of this receptor was occurring in response to a decrease of GABAergic neurons and/or activity. When this form of analysis was applied to the hippocampal formation (Fig. 5), a similar pattern was observed in sector CA1 (Benes et al. 1996b). In sector $C A 3$, however, the increase of $\mathrm{GABA}_{\mathrm{A}}$ receptor binding activity was found on nonpyramidal neurons, but not pyramidal cells, suggesting that a decrease of GABA-to-GABA interactions might be occurring in this sector of schizophrenics. 


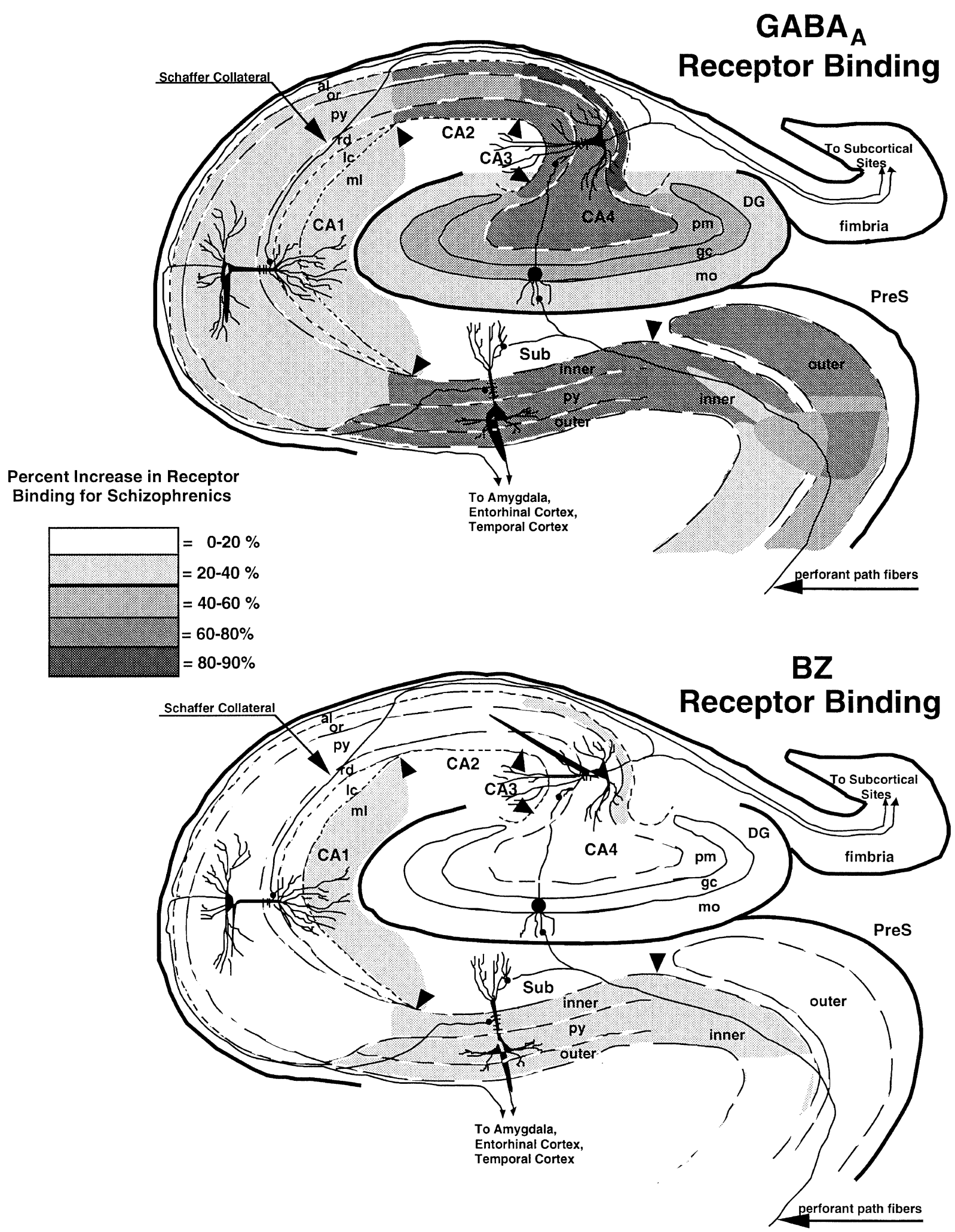

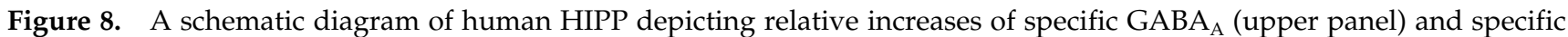
BZ (lower panel) receptor binding activity in SZ s compared to normal controls. The degree of shading in each diagram is proportion to the percent increase of receptor binding in SZs (refer to key in diagram). (Modified and reproduced from Benes et al. 1996b with permission.) 


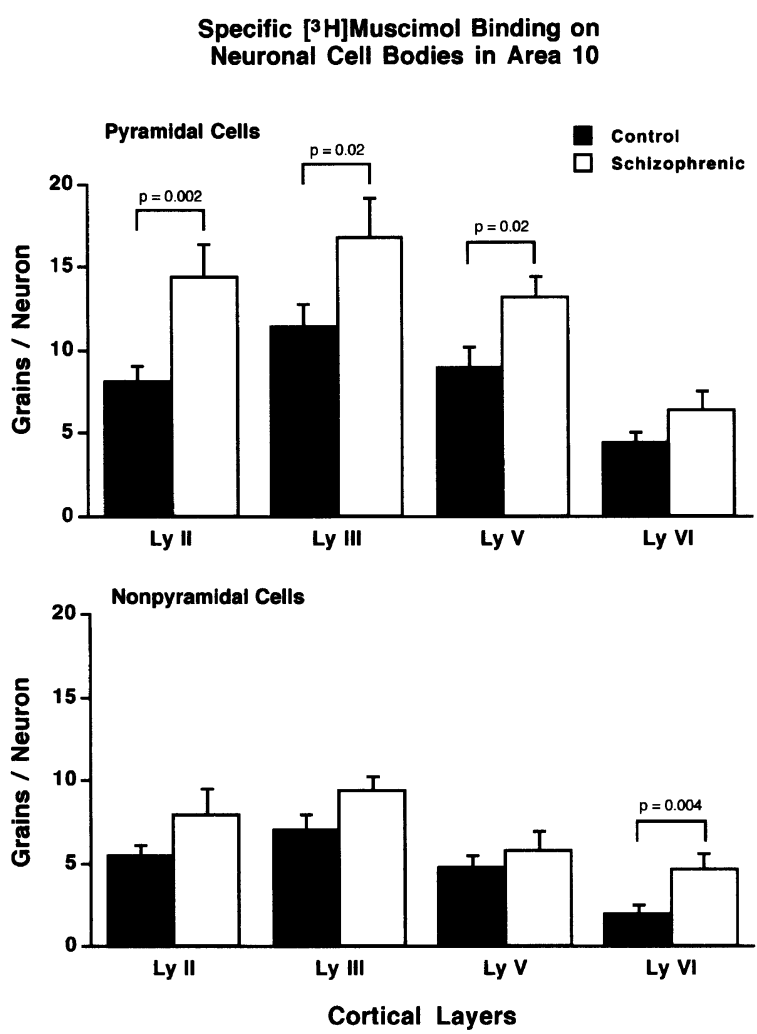

Figure 9. High resolution studies of $\mathrm{GABA}_{\mathrm{A}}$ receptor binding activity in various layers of the prefrontal cortex from normal controls (solid bars) and schizophrenic subjects (open bars). There is a marked increase of $\mathrm{GABA}_{\mathrm{A}}$ binding in layers II, III and V of the schizophrenics, but no change in layer VI. These changes are thought to represent a compensatory upregulation of this receptor in response to a loss of GABAergic cells and/or activity in this and other regions of the corticolimbic system. These data do not exclude the possibility, however, that the GABA receptor complex may be genetically abnormal in schizophrenia and that the increase of binding to the $\mathrm{GABA}_{\mathrm{A}}$ site might represent a primary defect. (Adapted from Benes et al. 1992.)

Taken together, these results consistently indicate that a disruption of inhibitory GABAergic neurons occurs in selective regions of the cerebral cortex. In the hippocampus, however, there appear to be more complex alterations that involve both inhibitory and disinhibitory GABA cells along the trisynaptic pathway of schizophrenics (Benes 1999; Benes and Berretta 2000b) and these changes would likely result in disruptions of the normal feedforward activity of this region (see Figure 5).

Altered Inputs to GABA Cells. The dopamine system has long been suspected of playing a role in the pathophysiology of schizophrenia (Kety and Matthysse 1972), even though convincing empiric evidence for a primary defect in this system has been lacking (Carlsson 1978). Seymour Kety was the first to suggest, how- ever, that subtle changes in connectivity could occur in the absence of any discernible biochemical alterations (Kety 1959). To determine whether such a defect is present in schizophrenia, it is now possible to visualize dopamine fibers using antibodies against TH (Lewis et al. 1987; Gaspar et al. 1989; Noack and Lewis 1989; Samson et al. 1990; Williams and Goldman-Rakic 1993).

A recent study of the distribution of TH-IR varicosities in the anterior cingulate and prefrontal cortices of schizophrenic brain has suggested that there may be a decrease of these fibers on pyramidal neurons, but an increase on interneurons in layer II of the anterior cingulate; this change was not observed in the prefrontal cortex (Benes et al. 1997a). In layers V and VI, there was a significant reduction in the density of TH-IR varicosities and this compares favorably with an analysis of fiber length in the prefrontal cortex of schizophrenics where a significant reduction was found in layer VI (Akil et al. 1999). In the anterior cingulate cortex, however, this change was only found in patients treated with neuroleptic drugs, whereas the apparent shift of TH-IR varicosities from pyramidal to nonpyramidal cells of layer II was found in all schizophrenic subjects, whether or not they were treated with antipsychotic medication (Benes et al. 1997a).

A subsequent post hoc analysis in which several different working models were considered suggested that these data might best be explained by a trophic shift of TH-IR fibers from pyramidal to nonpyramidal neurons (Benes 1998). A loss of GABAergic interneurons was not required for this pattern to occur, although it could co-exist with such a shift. If these findings were correct, they would suggest that dopaminergic afferents might be providing a non-adaptive hyperinnervation of a subpopulation of GABAergic interneurons, perhaps ones that are intrinsically impaired in schizophrenia. Since dopamine appears to exert an inhibitory effect on cortical GABA cells (Retaux et al. 1991), these findings would predict that an excessive release of dopamine under conditions of stress (Thierry et al. 1976; Roth et al. 1988) could lead to an impairment of GABAergic function and ultimately to a decompensation of the intrinsic circuitry in layer II of anterior cingulate cortex (Benes 1997).

\section{The Neurodevelopmental Hypothesis}

Cell Migration. The findings of a variety of changes in layer II of the anterior cingulate and prefrontal cortices has suggested the possibility that there might be a disturbance in the migration of neurons in the developing cortex of subjects with schizophrenia (Benes 1993). To investigate this possibility further, the distribution of nicotinamide adenine dinucleotide diaphorase (NADPH diaphorase) was examined in the prefrontal cortex of normal controls and schizophrenics (Akbarian et al. 1993). As shown in Figure 10, the results demonstrated 


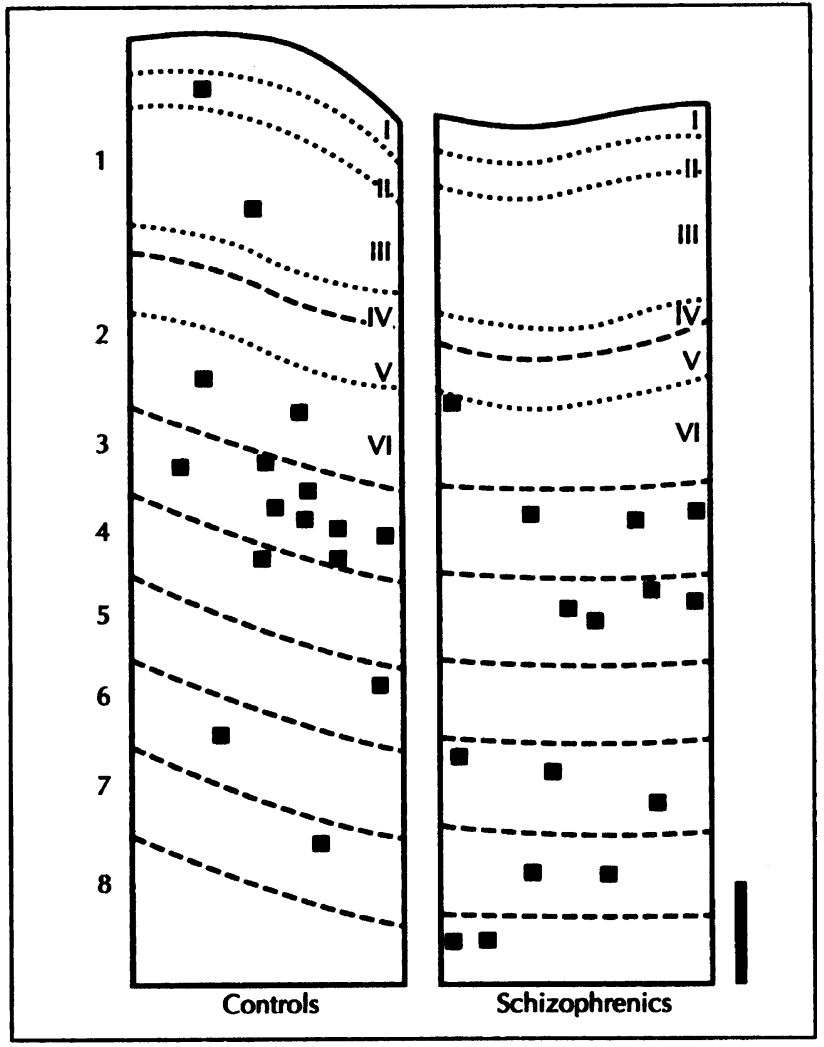

Figure 10. A schematic diagram depicting a disturbance in the migration of neurons in the prefrontal cortex of schizophrenic subjects. An increase of NADPH diaphorase positive neurons has been found in the subcortical white matter, while a decrease was observed in the cortical mantle. (Reproduced with permission from Akbarian et al. 1993.)

a significantly higher density of cells showing this marker in the subcortical white matter when compared to the cortical mantle. A similar pattern has been observed with MAP-2 staining (Andersen et al. 1996). Of significance to the current discussion is the fact that NADPH diaphorase has been co-localized to subpopulations of interneurons that are GABAergic in nature (Chesselet and Robbins 1989; Spike et al. 1993; Valtschanoff et al. 1993a,b; Davila et al. 1995; Gabbott and Bacon 1995, 1996a,b; Gabbott et al. 1997).

Reelin and Cortical Lamination. Another line of investigation that has pointed to a possible neurodevelopmental mechanism playing a role in the induction of a GABA defect in schizophrenia has come from studies of Reelin, a protein extracted from the Reeler mouse mutant. Reelin is believed to be secreted by a subclass of interneuron called Cajal-Retzius cells that may be GABAergic in nature (Pesold et al. 1998, 1999). These neurons are among the first to appear and are localized in layer I (Marin-Padilla 1984). During early development of the cortex, they interact with Martinotti cells in deeper laminae and may play a role in the formation of laminar patterns (Marin-Padilla 1984).

In schizophrenia and bipolar disorder, both Reelin and $\mathrm{GAD}_{67}$ mRNA have been found to be decreased in layer I and, to a lesser extent, layer II (Impagnatiello et al. 1998). These latter findings are consistent with both a cell counting study (Benes et al. 1991) and high resolution analyses of $\mathrm{GABA}_{\mathrm{A}}$ receptor binding activity (Benes et al. 1996c) showing preferential changes in layer II of the prefrontal cortex. These authors propose that a down-regulation of Reelin expression in this region of schizophrenic and bipolar brain may be due to either a genetic or an epigenetic factor. Since this protein is reduced in both schizophrenia and bipolar disorder, it seems more likely that the changes noted might be related to an environmental factor common to both. In this regard, it is noteworthy that obstetrical complications have been found to occur in both schizophrenia (Jacobsen and Kinney 1980) and bipolar disorder (Kinney et al. 1993, 1998), making it plausible that an insult early in life could influence the expression of this protein during adulthood.

Postnatal Ingrowth of Extrinsic Afferents. Important questions regarding the role of a neurodevelopmental disturbance in the induction of altered phenotypes of GABA cells are when and how such changes become manifest during the life cycle in individuals who carry the susceptibility genes for schizophrenia and bipolar disorder. One possibility is that the GABA cells are abnormal from birth; however, the clinical observation that most subjects with schizophrenia are relatively normal during childhood and early adolescence argues against this possibility. It is important to emphasize, however, that studies in rat suggest that the cortical GABA system continues to develop until the equivalent of early adolescence (Coyle and Yamamura 1976; Candy and Martin 1979; Johnston and Coyle 1980; Johnston 1988; Vincent et al. 1995).

Taking together these observations, a second possibility is that the GABA cells are relatively normal during childhood when they are also relatively immature, but become abnormal as their maturation process is completed as putative gene(s) associated with schizophrenia or bipolar disorder begin their expression. In this latter case, it would be assumed that both disorders would share common genes and these would be capable of altering the normal functioning of GABA cells. A third possibility is that the GABA cells are either relatively normal or abnormal during childhood, but their activity is quiescent while they await the ingrowth of an extrinsic fiber system, such as the dopaminergic afferents to the cortex (Verney et al. 1982; Kalsbeek et al. 1988). These latter fibers continue forming increased numbers of appositions with GABAergic interneurons until the early adult period (Benes et al. 1996a). 
Influence of Pre- and Postnatal Stress. The role of stress in the induction of changes in the cortical GABA system in schizophrenia and bipolar disorder is an interesting issue to explore. For example, glucocorticoid hormones have the ability to bind to the $\mathrm{GABA}_{\mathrm{A}}$ receptor (Sutanto et al. 1989) and have been found to directly increase its activity (Majewska et al. 1985; Lambert et al. 1987). In this regard, it is noteworthy that the binding of $\left[{ }^{3} \mathrm{H}\right]$ corticosterone is greatest in sector CA2 (McEwen 1982; Stumpf et al. 1989) where schizophrenics and bipolars both show a marked decrease of nonpyramidal neurons and also the largest increase of $\mathrm{GABA}_{\mathrm{A}}$ receptor binding (see above). It is important to point out, however, that stress is believed to increase rather than decrease the activity of the GABA system (Woodbury 1952; Feldman and Robinson 1968; Pfaff et al. 1971; Miller et al. 1978), although it is possible that chronic stress, particularly when preceded by stress in utero, might result in an eventual decrease in the activity of this transmitter system. This possibility is particularly intriguing when the marked sensitivity of GABAergic neurons to excitotoxic injury (Schwarcz and Coyle 1977) is taken into account. It is believed that cell death in this setting probably requires both an increase of excitatory activity and an increased release of glucocorticoid hormone (Sapolsky 1992).

Another important component to the stress response is the increased release of dopamine that occurs in the medial prefrontal cortex (see above). Relevant to this discussion is the fact that an increase of dopamine varicosities forming appositions with interneurons has been induced by exposing rats both pre- and postnatally to stress-related doses of corticosterone (Benes 1997). Thus, it is possible that the postnatal maturation of GABA cells in the cortex may be normally influenced by the ingrowth of dopamine fibers, but abnormally affected when this occurs in individuals for whom pre- and postnatal stress are co-morbid factors. In this latter case, it would have to be assumed that gene(s) involving the dopamine system and perhaps also cortical GABA cells would be affected by prenatal exposure to stress and would be permanently sensitized in such individuals.

\section{MODELLING ACTIVITY-DRIVEN CHANGES IN HIPPOCAMPAL GABA CELLS}

A conundrum that has presented itself from postmortem studies of the GABA system in schizophrenia and bipolar disorder is the following: Why are abnormalities preferentially detected in layer II of the anterior cingulate cortex and sectors CA3 and CA2 of the hippocampus? A potentially important clue that will help answer this question comes from studies of the connectivity of these regions. Layer II of the anterior cingulate cortex is known to receive a 'massive' projection from

\section{INTRAAMYGDALA INFUSION IN FREELY MOVING RAT}
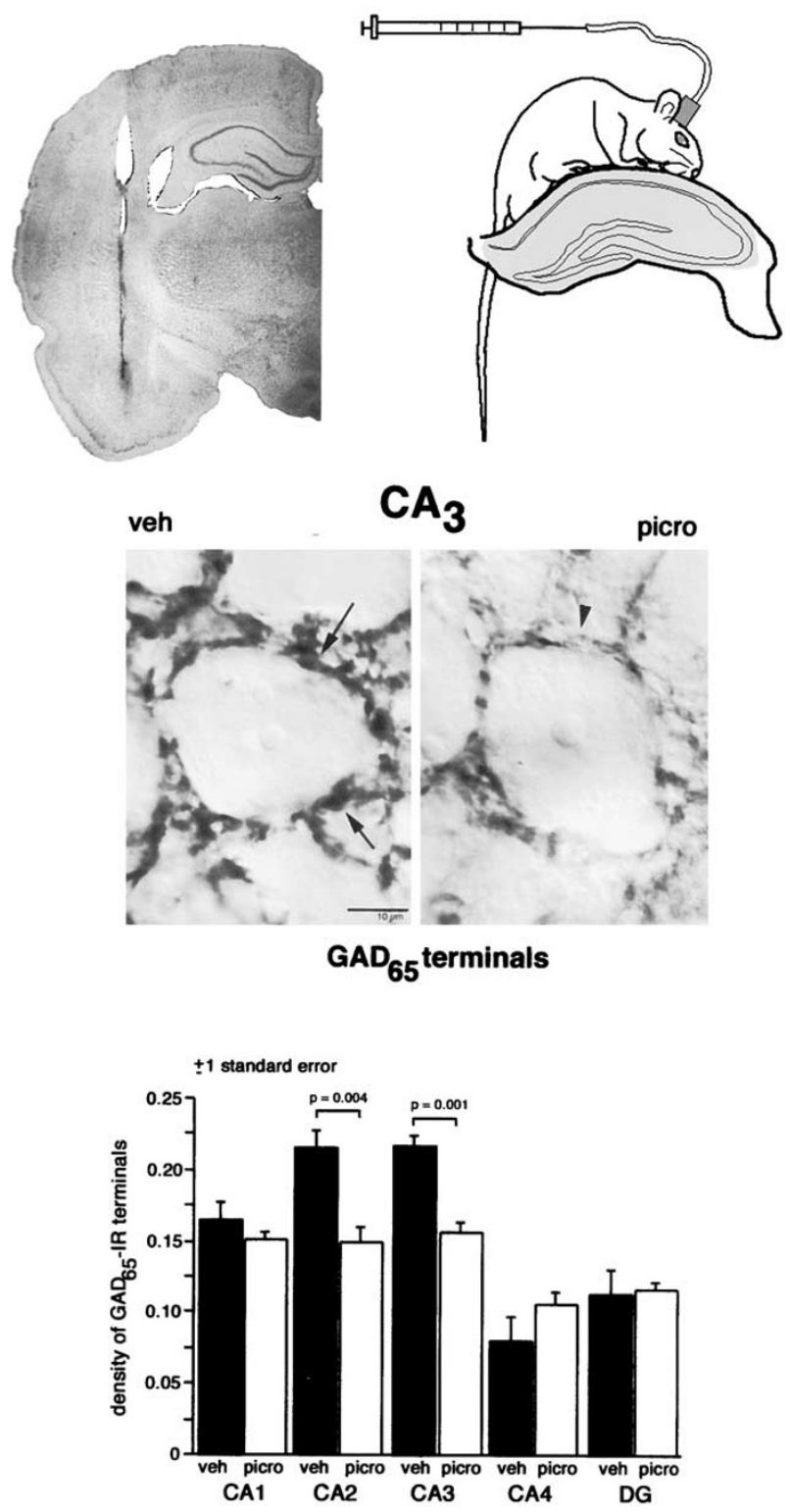

Figure 11. Stereotaxic local infusion of the $\mathrm{GABA}_{\mathrm{A}}$ receptor antagonist picrotoxin in the amygdala (needle track shown in upper left panel) of awake freely moving rats induced significant changes in densities of $\mathrm{GAD}_{65}$-positive terminals in hippocampus. The decrease, detectable around cell bodies of pyramidal neurons (middle panel), were selectively observed in sectors CA3 and CA2, but not CA1 (lower panel).

the basolateral nucleus of the amygdala (Van Hoesen et al. 1993), whereas sectors CA3 and CA2 also receive a substantial input from this same complex (Pikkarainen et al. 1999). Taken together with other evidence (Longson et al. 1996; Benes and Berretta 2000a), it seems plausible that the changes in the GABA system described above may potentially be related to an increased inflow of ac- 
tivity from this key limbic region. To explore the possibility that changes in the cortical and hippocampal GABA system in schizophrenia could be related to an increased inflow of activity originating in the amygdala, a 'partial' animal model has been developed (Berretta et al. 2001).

When the $\mathrm{GABA}_{\mathrm{A}}$ antagonist, picrotoxin, is infused locally into the basolateral nuclear complex of awake, freely moving rats, within 2 hours, a marked decrease in the density of both the 65 and $67 \mathrm{kDalton}$ isoforms of GAD-IR terminals can be detected on neuron somata in sectors CA3 and CA2, but not CA1 (Figure 11). In anterograde tracer studies, amygdalo-hippocampal projection fibers show a similar distribution. Overall, these results suggest that activation of afferents from the basolateral nucleus is associated with the induction of significant changes in the GABA system in the hippocampus with a subregional distribution that is remarkably similar to that found in schizophrenia and bipolar disorder. Under pathological conditions, an excessive discharge of excitatory activity emanating from the amygdala could be capable of altering inhibitory modulation along the trisynaptic pathway and may potentially contribute to disturbances of GABAergic function in neuropsychiatric disorders. Such 'partial' modelling in rodents will provide an important strategy for deciphering the effect of altered corticolimbic circuits in schizophrenia and bipolar disorder.

\section{CONCLUSIONS}

The cortical and hippocampal GABA systems consists of many different subclasses of interneurons, each having unique phenotypes defined by their morphology, neuropeptide content, electrophysiological properties, and synaptic connectivity. GABAergic cells engage in complex interactions not only with projection neurons, but also with one another. The intricate networks derived from these interactions are associated with the generation of both oscillatory rhythms and detailed aspects of discriminative information processing. A defect in even one component of such a system could potentially have profound implications for the functioning of local circuits, as well as larger scale macrocircuits within the corticolimbic system. Stated simply, GABAergic interneurons are critical to the formulation of complex behaviors and a defect in their functioning can give rise to a broad array of disturbances in cognitive function, like those seen in schizophrenia.

In reviewing the postmortem investigations that have been directed at the study of this system, it is clear that there have been some inconsistencies, particularly with regard to cell counting findings. There are many different confounding factors that can be invoked to explain failures to replicate and these vary according to the types of methodology that have been employed. Nevertheless, when this literature is viewed as a totality, including not only cell counting studies, but also cytochemical ones in which immunocytochemistry, receptor binding autoradiography and in situ hybridization have been employed, some form of dysfunction in the GABAergic system brain appears to be present in the cortex of schizophrenics. The fact that similar findings are also being reported in bipolar disorder suggests that such a defect may be related to a common environmental factor, perhaps that related to obstetrical complications. Indeed, the neurodevelopmental hypothesis of schizophrenia (and by extrapolation, bipolar disorder) has received its most convincing evidence from studies of the GABA system.

An important question raised by these findings is whether the GABAergic interneuron might potentially be a common site for the action of drugs that are used in the treatment of both schizophrenia and bipolar disorder. Indeed, GABA-mimetic drugs, such as mood-stabilizing anticonvulsants, show efficacy in the treatment of both schizophrenia (Wassef et al. 1999) and bipolar disorder (Bowden 1998), although patients with affective disorder show a more striking beneficial effect. Recent studies demonstrating direct interactions between the dopamine and serotonin systems with GABAergic neurons in the cortex, as well as the expression of their respective receptor systems in these interneurons, are also consistent with this idea.

In the years to come, continued investigations of the GABA system in rodent, primate, and human brain and the characterization of changes in specific phenotypic subclasses of interneurons in schizophrenia and bipolar disorder will undoubtedly provide important new insights into how the integration of macro- and microcircuitry in the corticolimbic system is altered in health and disease. Most importantly, it will be important to use increasingly sophisticated information regarding GABAergic cells to identify the precise ways in which neuroleptic drugs can influence the structural and functional integrity of this transmitter system. Information of this type may eventually point the way toward novel approaches to the treatment of devastating neuropsychiatric disorders.

\section{ACKNOWLEDGMENTS}

This work has been supported by grants from the National Institutes of Health (MH00423, MH42261, MH31862, MH31154) and the Stanley Foundation.

\section{REFERENCES}

Abi-Dargham A, Laruelle M, Krystal J, D'Souza C, Zoghbi S, Baldwin RM, Seibyl J, Mawlawi O, de Erasquin G, Charney D, Innis RB (1999): No evidence of altered in 
vivo benzodiazepine receptor binding in schizophrenia. Neuropsychopharmacology 20:650-661

Acsady L, Gorcs TJ, Freund TF (1996a): Different populations of vasoactive intestinal polypeptide-immunoreactive interneurons are specialized to control pyramidal cells or interneurons in the hippocampus. Neuroscience 73:317-334

Acsady L, Arabadzisz D, Freund TF (1996b): Correlated morphological and neurochemical features identify different subsets of vasoactive intestinal polypeptideimmunoreactive interneurons in rat hippocampus. Neuroscience 73:299-315

Adler LA, Pachtman E, Franks FD, Pecevich M, Waldo MD, Freedman R (1982): Neurophysiological evidence for a defect in neuronal mechanisms involved in sensory gating in schizophrenia. Biol Psychiatry 17:639-654

Agmon A, Connors BW (1992): Correlation between intrinsic firing patterns and thalamocortical synaptic responses of neurons in mouse barrel cortex. J Neurosci 12:319-329

Akbarian S, Bunney WE, Potkin SG, Wigal SB, Hagman JD, Sandman CA, Jones EG (1993): Altered distribution of nicotinamide-adenine dinucleotide phosphate-diaphorase cells in frontal lobe of schizophrenics implies disturbances of cortical development. Arch Gen Psychiatry 50:227-230

Akbarian S, Kim JJ, Potkin SG, Hagman JO, Tafazzoli A, Bunney WE, Jones EG (1995): Gene expression for glutamic acid decarboxylase is reduced without loss of neurons in prefrontal cortex of schizophrenics. Arch Gen Psychiatry 52:258-278

Akil M, Pierri JN, Whitehead RE, Edgar CL, Mohila C, Sampson AR, Lewis DA (1999): Lamina-specific alterations in the dopamine innervation of the prefrontal cortex in schizophrenic subjects. Am J Psychiatry 156:1580-1589

Alloway KD, Burton H (1991): Differential effects of GABA and bicuculline on rapidly- and slowly-adapting neurons in primary somatosensory cortex of primates. Exp Brain Res 85:598-610

Alloway KD, Rosenthal P, Burton H (1989): Quantitative measurements of receptive field changes during antagonism of GABAergic transmission in primary somatosensory cortex of cats. Exp Brain Res 78:514-532

Amzica F, Steriade M (1995): Disconnection of intracortical synaptic linkages disrupts synchronization of a slow oscillation. J Neurosci 15:4658-4677

Andersen P, Eccles JC, Loyning Y (1964): Location of synaptic inhibitory synapses on hippocampal pyramids. J Neurophysiol 27:592-607

Andersen SA, Volk DW, Lewis DA (1996): Increased density of microtubule associated protein 2-immunoreactive neurons in the prefrontal white matter of schizophrenic subjects. Schizophr Res 19:111-119

Anwyl R (1991): Modulation of vertebrate neuronal calcium channels by neurotransmitters. Brain Res Rev 16:265-281

Arnold SE, Franz BR, Gur RC, Gur RE, Shapiro RM, Moberg PJ, Trojanowski JQ (1995): Smaller neuron size in schizophrenia in hippocampal subfields that mediate cortical-hippocampal interactions. Am J Psychiatry 152:738-748
Ball S, Busatto GF, David AS, Jones SH, Hemsley DR, Pilowsky LS, Costa DC, Ell PJ, Kerwin RW (1998): Cognitive functioning and GABAA/benzodiazepine receptor binding in schizophrenia: A 123I-iomazenil SPET study. Biol Psychiatry 43:107-117

Beasley CL, Reynolds GP (1997): Parvalbumin-immunoreactive neurons are reduced in the prefrontal cortex of schizophrenics. Schizophr Res 24:349-355

Beaulieu C, Kisvarday Z, Somogyi P, Cynader M, Cowey A (1992): Quantitative distribution of GABA-immunopositive and -immunonegative neurons and synapses in the monkey striate cortex (area 17). Cerebr Cortex 2:295-309

Benes FM (1993): Neurobiological investigations in cingulate cortex of schizophrenic brain. Schizophr Bull 19:537-549

Benes FM (1995): Is there a neuroanatomic basis for schizophrenia? Neuroscientist 1:104-115

Benes FM (1997): The role of stress and dopamine-GABA interactions in the vulnerability for schizophrenia. J Psychiatr Res 31:257-275

Benes FM (1998): Model generation and testing to probe neural circuitry in the cingulate cortex of postmortem schizophrenic brain. Schizophr Bull 24:219-230

Benes FM (1999): Evidence for altered trisynaptic circuitry in schizophrenic hippocampus. Biol Psychiatry 46:589-599

Benes FM, Berretta S (2000a): Amygdalo-entorhinal inputs to the hippocampal formation in relation to schizophrenia. NY Acad Sci 911:293-304

Benes FM, Paskevich PA, Domesick VB (1983): Haloperidolinduced plasticity of axon terminals in rat substantia nigra. Science 221:969-971

Benes FM, Vincent SL, Molloy R (1993): Dopamine-immunoreactive axon varicosities form nonrandom contacts with GABA-immunoreactive neurons of rat medial prefrontal cortex. Synapse 15:285-295

Benes FM, Todtenkopf MS, Taylor JB (1997a): Differential distribution of tyrosine hydroxylase fibers on small and large neurons in layer II of anterior cingulate cortex of schizophrenic brain. Synapse 25:80-92

Benes FM, Paskevich PA, Davidson J, Domesick VB (1985): Synaptic rearrangements in medial prefrontal cortex of haloperidol- treated rats. Brain Res 348:15-20

Benes FM, Vincent SL, Molloy R, Khan Y (1996a): Increased interaction of dopamine-immunoreactive varicosities with GABA neurons of rat medial prefrontal cortex occurs during the postweanling period. Synapse 23:237-245

Benes FM, Khan Y, Vincent SL, Wickramasinghe R (1996b): Differences in the subregional and cellular distribution of GABAA receptor binding in the hippocampal formation of schizophrenic brain. Synapse 22:338-349

Benes FM, Vincent S, Marie A, Khan Y (1996c): Upregulation of GABA-A receptor binding on pyramidal neurons of prefrontal cortex in schizophrenic subjects. Neuroscience 75:1021-1031

Benes FM, Kwok EW, Vincent SL, Todtenkopf MS (1998): A reduction of nonpyramidal cells in sector CA2 of schizophrenics and manic depressives. Biol Psychiatry 44:88-97

Benes FM, McSparren J, Bird ED, Vincent SL, SanGiovanni JP (1991): Deficits in small interneurons in prefrontal and anterior cingulate cortex of schizophrenic and schizoaffective patients. Arch Gen Psychiatry 48:996-1001 
Benes FM, Vincent SL, Alsterberg G, Bird ED, SanGiovanni JP (1992): Increased GABAA receptor binding in superficial layers of cingulate cortex in schizophrenics. J Neurosci 12:924-929

Benes FM, Vincent SL, Todtenkopf M (2001): The density of pyramidal and nonpyramidal neurons in anterior cinculate cortex of schizophrenic and bipolar subjects. Biol Psychiat, in press

Benes FM, Wickramasinghe R, Vincent SL, Khan Y, Todtenkopf M (1997b): Uncoupling of GABA(A) and benzodiazepine receptor binding activity in the hippocampal formation of schizophrenic brain. Brain Res 755:121-129

Benes FM, Berretta S (2000b): Amygdalo-entorhinal inputs to the hippocampal formation in relation to schizophrenia. Ann N Y Acad Sci 911:293-304

Benes FM, Lange N (2001): Two dimensional versus three dimensional cell counting: A practical perspective. Trends Neurosci, 24:11-17

Benes FM, Taylor JB, Cunningham M (2000): Convergence and plasticity of monoaminergic systems in the medial prefrontal cortex during the postnatal period: Implications for the development of psychopathology. Cerebr Cortex, 10:1014-1027

Benes FM, Todtenkopf MS (1998): Meta-Analysis of nonpyramidal neuron (NP) loss in layer II in anterior cingulate cortex (ACCX-II) from three studies of postmortem schizophrenic brain. Soc Neurosci Abstr 24(2):1275

Berretta S, Munno DW, Benes FM (2001): Amygdalar activation alters the hippocampal GABA system: 'Partial' modelling for postmortem changes in schizophrenia. J Compar Neurol, 431:129-138

Bird ED, Barnes J, Iversen L, Spokes EG, Mackay AVP, Shepherd M (1977): Increased brain dopamine and reduced glutamic acid decarboxylase and choline acetyl transferase activity in schizophrenia and related psychoses. Lancet 3:1157-1159

Blackwood DHR, Young AH, McQueen JK, Martin MJ, Roxborough, Muir WJ, St. Clair DM, Kean DM (1991): Magnetic resonance imaging in schizophrenia: Altered brain morphology associated with P300 abnormalities and eye tracking dysfunction. Biol Psychiatry 30:753-769

Bowden CL (1998): New concepts in mood stabilization: Evidence for the effectiveness of valproate and lamotrigine. Neuropsychopharmacology 19:194-199

Bowers G, Cullinan WE, Herman JP (1998): Region-specific regulation of glutamic acid decarboxylase (GAD) mRNA expression in central stress circuits. J Neurosci 18:5938-5947

Braff DL, Heaton R, Kuck J, Cullum M, Moranville J, Grant I, Zisook S (1991): The generalized pattern of neuropsychological deficits in outpatients with chronic schizophrenia with heterogeneous Wisconsin Card Sorting Test results. Arch Gen Psychiatry 48:891-898

Bragin A, Jando G, Nadasdy Z, Hetke J, Wise K, Buzsaki G (1995): Gamma (40-100 Hz) oscillation in the hippocampus of the behaving rat. J Neurosci 15:47-60

Buhl EH, Halasy K, Somogyi P (1994): Diverse sources of hippocampal unitary inhibitory postsynaptic potentials and the number of synaptic release sites. Nature 368: $823-828$
Busatto GF, Pilowsky LS, Costa DC, Ell PJ, David AS, Lucey JV, Kerwin RW (1997): Correlation between reduced in vivo benzodiazepine receptor binding and severity of psychotic symptoms in schizophrenia. Am J Psychiatry 154:56-63

Buzsaki G (1984): Feed-forward inhibition in the hippocampal formation. Prog Neurobiol 22:131-153

Buzsaki G (1997): Functions for interneuronal nets in the hippocampus. Can J Physiol Pharmacol 75:508-515

Buzsaki G, Eidelberg E (1983): Phase relations of hippocampal projection cells and interneurons to theta activity in the anesthetized rat. Brain Res 266:334-339

Buzsaki G, Chrobak JJ (1995): Temporal structure in spatially organized neuronal ensembles: A role for interneuronal networks. Curr Opin Neurobiol 5:504-510

Buzsaki G, Penttonen M, Nadasdy Z, Bragin A (1996): Pattern and inhibition-dependent invasion of pyramidal cell dendrites by fast spikes in the hippocampus in vivo. Proc Natl Acad Sci U S A 93:9921-9925

Buzsaki G, Horvath Z, Urioste R, Hetke J, Wise K (1992): High-frequency network oscillation in the hippocampus. Science 256:1025-1027

Cameron N (1938): Reasoning, regression and communication in schizophrenics. Psychol Rev Monogr 50:1-33

Candy JM, Martin IL (1979): The postnatal development of the benzodiazepine receptor in the cerebral cortex and cerebellum of the rat. J Neurochem 32:655-658

Carlsson A (1978): Does dopamine have a role in schizophrenia? Biol Psychiatry 13:3-21

Cauli B, Audinat E, Lambolez B, Angulo MC, Ropert N, Tsuzuki K, Hestrin S, Rossier J (1997): Molecular and physiological diversity of cortical nonpyramidal cells. J Neurosci 17:3894-3906

Chesselet MF, Robbins E (1989): Characterization of striatal neurons expressing high levels of glutamic acid decarboxylase messenger RNA. Brain Res 492:237-244

Conde' F, Lund JS, Jacobowitz DM, Baimbridge KG, Lewis DA (1994): Local circuit neurons immunoreactive for calretinin, calbindin D-28k or parvalbumin in monkey prefrontal cortex: Distribution and morphology. J Comp Neurol 341:95-116

Coyle JT, Yamamura HI (1976): Neurochemical aspects of the ontogenesis of GABAergic neurons in the rat brain. Brain Res 118:429-440

Cross AJ, Crow TJ, Owen F (1979): Gamma-aminobutyric acid in the brain in schizophrenia. Lancet 1:560-561

Csicsvari J, Hirase H, Czurko A, Mamiya A, Buzsaki G (1999): Oscillatory coupling of hippocampal pyramidal cells and interneurons in the behaving rat. J Neurosci 19(1):274-287

Dantzker JL, Callaway EM (2000): Laminar sources of synaptic input to cortical inhibitory interneurons and pyramidal neurons. Nature Neurosci 3:701-707

Davidoff SA, Benes FM (1998): High-resolution scatchard analysis shows D1 receptor binding on pyramidal and nonpyramidal neurons. Synapse 28:83-90 
Davila JC, Megias M, Andreu MJ, Real MA, Guirado S (1995): NADPH diaphorase-positive neurons in the lizard hippocampus: A distinct subpopulation of GABAergic interneurons. Hippocampus 5:60-70

Daviss SR, Lewis DA (1995): Local circuit neurons of the prefrontal cortex in schizophrenia: Selective increase in the density of calbindin-immunoreactive neurons. Psychiatry Res 59:81-96

Dean B, Hussain T, Hayes W, Scarr E, Kitsoulis S, Hill C, Opeskin K, Copolov DL (1999): Changes in serotonin2A and $\operatorname{GABA}(\mathrm{A})$ receptors in schizophrenia: Studies on the human dorsolateral prefrontal cortex. J Neurochem 72:1593-1599

DeFelipe J, Hendry SH, Jones EG (1989a): Visualization of chandelier cell axons by parvalbumin immunoreactivity in monkey cerebral cortex. Proc Natl Acad Sci U S A 86:2093-2097

DeFelipe J, Hendry SH, Jones EG (1989b): Synapses of double bouquet cells in monkey cerebral cortex visualized by calbindin immunoreactivity. Brain Res 503:49-54

DeFelipe J, Hendry SH, Hashikawa T, Molinari M, Jones EG (1990): A microcolumnar structure of monkey cerebral cortex revealed by immunocytochemical studies of double bouquet cell axons. Neuroscience 37:655-673

de Lima AD, Morrison JH (1989): Ultrastructural analysis of somatostatin-immunoreactive neurons and synapses in the temporal and occipital cortex of the macaque monkey. J Comp Neurol 283:212-227

del Rio MR, DeFelipe J (1995): A light and electron microscopic study of calbindin D-28k immunoreactive double bouquet cells in the human temporal cortex. Brain Res 690:133-140

Descarries L, Beaudet A, Watkins KC (1975): Serotonin nerve terminals in adult rat neocortex. Brain Res 100:563-588

Detre TP, Jarecki HG (1971): Schizophrenic disorders. Modern Psychiatric Treatment. Philadelphia, J.B. Lippincott, pp 108-116

Eccles JC (1984): The cerebral neocortex. A theory of its operation. In Jones EG, Peter A, (eds), Cerebral Cortex. Functional Properties of Cortical Cells. New York, Plenum Press

Fairen A, DeFelipe J, Regidor J (1982): Nonpyramidal neurons. In Peter A, Jones EG (eds), Cerebral Cortex. New York, Plenum Press, pp 201-253

Feldblum S, Ackerman RF, Tobin AJ (1990): Long-term increase of glutamate decarboxylase mRNA in a rat model of temporal lobe epilepsy. Neuron 5:361-371

Feldblum S, Anoal M, Lapsher S, Cumoulin A, Privat A (1998): Partial deafferentation of the developing rat spinal cord delays the spontaneous repression of $\mathrm{GAD}_{67}$ mRNAs in spinal cells. Perspect Development Neurobiol 5:131-143

Feldman W, Robinson, S (1968): Electrical activity of the brain in adrenalectomized rats with implanted electrodes. J Neurological Sci 6:1-8

Fonseca M, Soriano E, Ferrer I, Martinez A, Tunon T (1993): Chandelier cell axons identified by parvalbumin-immunoreactivity in the normal human temporal cortex and in Alzheimer's disease. Neuroscience 55:1107-1116
Fraser DD, MacVicar BA (1991): Low-threshold transient calcium current in rat hippocampal lacunosum-moleculare interneurons: Kinetics and modulation by neurotransmitters. J Neurosci 11:2812-2820

Freund TF, Gulyas AI (1991): GABAergic interneurons containing calbindin D28K or somatostatin are major targets of GABAergic basal forebrain afferents in the rat neocortex. J Comp Neurol 314:187-199

Freund TF, Buzsaki G (1996): Interneurons of the hippocampus. Hippocampus 6:347-470

Gabbott PL, Bacon SJ (1995): Co-localisation of NADPH diaphorase activity and GABA immunoreactivity in local circuit neurones in the medial prefrontal cortex (mPFC) of the rat. Brain Res 699:321-328

Gabbott PL, Bacon SJ (1996a): Local circuit neurons in the medial prefrontal cortex (areas 24a,b,c, 25 and 32) in the monkey. I. Cell morphology and morphometrics. J Comp Neurol 364:567-608

Gabbott PL, Bacon SJ (1996b): Local circuit neurons in the medial prefrontal cortex (areas 24a,b,c, 25 and 32) in the monkey. II. Quantitative areal and laminar distributions. J Comp Neurol 364:609-636

Gabbott PL, Dickie BG, Vaid RR, Headlam AJ, Bacon SJ (1997): Local-circuit neurones in the medial prefrontal cortex (areas 25, 32 and 24b) in the rat: morphology and quantitative distribution. J Comp Neurol 377:465-499

Gaspar P, Berger B, Febvret A, Vigny A, Henry JP (1989): Catecholamine innervation of the human cerebral cortex as revealed by comparative immunohistochemistry of tyrosine hydroxylase and dopamine beta-hydroxylase. J Comp Neurol 279:249-271

Gellman RL, Aghajanian GK (1993): Pyramidal cells in piriform cortex receive a convergence of inputs from monoamine activated GABAergic interneurons. Brain Res 600:63-73

Gellman RL, Aghajanian GK (1994): Serotonin receptormediated excitation of interneurons in piriform cortex: Antagonism by atypical antipsychotic drugs. Neuroscience 58:515-525

Gibson JR, Beierlein M, Connors BW (1999): Two networks of electrically coupled inhibitory neurons in neocortex. Nature 402:75-79

Goldman-Rakic PS, Leranth C, Williams SM, Mons N, Geffard M (1989): Dopamine synaptic complex with pyramidal neurons in primate cerebral cortex. Proc Natl Acad Sci U S A 86:9015-9019

Guidotti A, Auta J, Davis JM, Dwivedi Y, Grayson DR, Impagnatiello F, Pandey G, Pesold C, Sharma R, Uzunov D, Costa E (2000): Decrease in Reelin and glutamate acid decarboxylase ${ }_{67}\left(\mathrm{GAD}_{67}\right)$ expression in schizophrenia and bipolar disorder. Arch Gen Psychiatry, 57:1061-1069

Gulyas AI, Hajos N, Freund TF (1996): Interneurons containing calretinin are specialized to control other interneurons in the rat hippocampus. J Neurosci 16:3397-3411

Gulyas AI, Toth K, Danos P, Freund TF (1991): Subpopulations of GABAergic neurons containing parvalbumin, 
calbindin D28k, and cholecystokinin in the rat hippocampus. J Comp Neurol 312:371-378

Gupta A, Wang Y, Markram H (2000): Organizing principles for a diversity of GABAergic interneurons and synapses in the neocortex. Science 287:273-278

Hanada S, Mita T, Nishinok N, Tankaka C (1987): 3H-Muscimol binding sites increased in autopsied brains of chronic schizophrenics. Life Sci 40:259-266

Heckers S, Rausch SL, Goff D, Savage CR, Schacter DL, Fischman AJ, Alpert NM (1998): Impaired recruitment of the hippocampus during conscious recollection in schizophrenia. Nature Neurosci 1:318-323

Heckers S, Stone D, Walsh I, Shick J, Koul P, Benes FM (2001): Decreased hippocampal expression of glutamic acid decarboxyase (GAD) 65 and 67 mRNA in bipolar disorder, but not schizophrenia. Soc Neuros Abs, in press

Hendry SHC, Houser CR, Jones EG, Vaughn JE (1983): Synaptic organization of immunocytochemically identified GABA neurons in the monkey sensory-motor cortex. J Neurocytol 12:639-660

Hendry SH, Jones EG, Emson PC, Lawson DE, Heizmann CW, Streit P (1989): Two classes of cortical GABA neurons defined by differential calcium binding protein immunoreactivities. Exp Brain Res 76:467-472

Hof PR, Luth H-J, Rogers JH, Celio MR (1993): Calciumbinding proteins define subpopulations of interneurons in cingulate cortex. In Vogt BA, Gabriel M (eds), Neurobiology of Cingulate Cortex and Limbic Thalamus: A Comprehensive Handbook. Boston: Birkhauser

Hornung JP, Celio MR (1992): The selective innervation by serotoninergic axons of calbindin-containing interneurons in the neocortex and hippocampus of the marmoset. J Comp Neurol 320:457-467

Houser CR, Hendry SH, Jones EG, Vaughn JE (1983): Morphological diversity of immunocytochemically identified GABA neurons in the monkey sensory-motor cortex. J Neurocytol 12:617-638

Huntley GW, Morrison JH, Prikhozhan A, Sealfon SC (1992): Localization of multiple dopamine receptor subtype mRNAs in human and monkey motor cortex and striatum. Mol Brain Res 15:181-188

Impagnatiello F, Guidotti AR, Pesold C, Dwivedi Y, Caruncho H, Pisu MG, Uzunov DP, Smalheiser NR, Davis JM, Pandey GN, Pappas GD, Tueting P, Sharma RP, Costa E (1998): A decrease of reelin expression as a putative vulnerability factor in schizophrenia. Proc Natl Acad Sci U S A 95:15718-15723

Iritani S, Kuroki N, Ikeda K, Kazamatsuri H (1999): Calbindin immunoreactivity in the hippocampal formation and neocortex of schizophrenics. Prog Neuropsychopharmacol Biol Psychiatry 23:409-421

Jacobs KM, Donoghue JP (1991): Reshaping the cortical motor map by unmasking latent intracortical connections. Science 251:944-947

Jacobsen B, Kinney DK (1980): Perinatal complications in adopted and non-adopted schizophrenics and their controls: Preliminary results. Acta Psychiatry Scand 238:103-123

Jakab RL, Goldman-Rakic PS (1998): 5-Hydroxytryptamine
2A serotonin receptors in the primate cerebral cortex: possible site of action of hallucinogenic and antipsychotic drugs in pyramidal cell apical dendrites. Proc Natl Acad Sci U S A 95:735-740

Jefferys JG, Traub RD, Whittington MA (1996): Neuronal networks for induced ' $40 \mathrm{~Hz}$ ' rhythms. Trends Neurosci 19:202-208

Johnston MV (1988): Biochemistry of neurotransmitters in cortical development. In Peter A, Jones EG (eds), Cerebral Cortex. New York, Plenum Press, pp 211-236

Johnston MV, Coyle JT (1980): Ontogeny of neurochemical markers for noradrenergic, GABAergic and cholinergic neurons in neocortex lesioned with methylazoxymethanol acetate. J Neurochem 34:1429-1441

Jones EG (1987): GABA-peptide neurons in primate cerebral cortex. J Mind Behav 8:519-536

Jones EG (1990): The role of afferent activity in the maintenance of primate neocortical function. J Exp Biol 153:155-176

Jones EG (1993): GABAergic neurons and their role in cortical plasticity in primates. Cerebral Cortex 3:361-372

Jones EG, Hendry SHC (1984): Basket cells. In Peter A, Jones EG (eds), Cerebral Cortex. New York, Plenum Press, pp 309-336

Kalsbeek A, Voorn P, Buijs RM, Pool CW, Uylings HB (1988): Development of the dopaminergic innervation in the prefrontal cortex of the rat. J Comp Neurol 269:58-72

Kalus P, Senitz D, Beckmann H (1997): Altered distribution of parvalbumin-immunoreactive local circuit neurons in the anterior cingulate cortex of schizophrenic patients. Psychiatry Res 75:49-59

Katsumaru H, Kosaka T, Heizmann CW, Hama K (1988): Gap junctions on GABAergic neurons containing the calcium-binding protein parvalbumin in the rat hippocampus (CA1 region). Exp Brain Res 72:363-370

Kaufman DL, Houser CR, Tobin AJ (1991): Two forms of the $\gamma$-aminobutyric acid synthetic enzyme glutamate decarboxylase have distinct intraneuronal distributions and cofactor interactions. J Neurochem 56:720-723

Kawaguchi Y, Kubota Y (1993): Correlation of physiological subgroupings of nonpyramidal cells with parvalbuminand calbindinD28k-immunoreactive neurons in layer $\mathrm{V}$ of rat frontal cortex. J Neurophysiol 70:387-396

Kawaguchi Y, Kubota Y (1995): Local circuit neurons in the frontal cortex and the neostriatum. In Kimura M, Graybiel AM (eds), Functions of the Cortico-Basal Ganglia Loop. Tokyo, Springer-Verlag

Kawaguchi Y, Kubota Y (1996): Physiological and morphological identification of somatostatin- or vasoactive intestinal polypeptide-containing cells among GABAergic cell subtypes in rat frontal cortex. J Neurosci 16:2701-2715

Kawaguchi Y, Katsumaru H, Kosaka T, Heizmann CW, Hama K (1987): Fast spiking cells in rat hippocampus (CA1 region) contain the calcium-binding protein parvalbumin. Brain Res 416:369-374

Kerns JM, Sierens DK, Kao LC, Klawans HL, Carvey PM (1992): Synaptic plasticity in the rat striatum following 
chronic haloperidol treatment. Clin Neuropharmacol 15:488-500

Kety S (1959): Biochemical theories of schizophrenia. Part I of a two-part critical review of current theories and of the evidence used to support them. Science 129:15281596

Kety S, Matthysse S (1972): Prospects for research on schizophrenia. An overview. Neurosci Res Bull 10:456-467

Kinney DK, Yurgelun-Todd DA, Tohen M, Tramer S (1998): Pre- and perinatal complications and risk for bipolar disorder: A retrospective study. J Affect Dis, 50:117-124

Kinney DK, Yurgelun-Todd DA, Levy DL, Medoff D, Lajonchere CM, Radford-Paregol M (1993): Obstetrical complications in patients with bipolar disorder and their siblings. Psychiatry Res 48:47-56

Kisvarday ZF, Beaulieu C, Eysel UT (1993): Network of GABAergic large basket cells in cat visual cortex (area 18): Implication for lateral disinhibition. J Comp Neurol 327:398-415

Kosaka T (1983): Axon initial segments of the granule cell in the rat dentate gyrus: Synaptic contacts on bundles of axon initial segments. Brain Res 274:129-134

Krnjevic K (1987): GABAergic inhibition in the neocortex. J Mind Behav 8:537-548

Kubota Y, Hattori R, Yui Y (1994): Three distinct subpopulations of GABAergic neurons in rat frontal agranular cortex. Brain Res 649:159-173

Kyriazi HT, Carvell GE, Brumberg JC, Simons DJ (1996): Quantitative effects of GABA and bicuculline methiodide on receptive field properties of neurons in real and simulated whisker barrels. J Neurophysiol 75:547-560

Laezza F, Doherty JJ, Dingledine R (1999): Long-term depression in hippocampal interneurons: Joint requirement for pre- and postsynaptic events. Science 285:1411-1414

Lambert JJ, Peters JA, Cottrell GA (1987): Actions of synthetic and endogenous steroids on the GABAA receptor. Trends Pharmacol Sci 8:224-227

Le Moine C, Gaspar P (1998): Subpopulations of cortical GABAergic interneurons differ by their expression of D1 and D2 dopamine receptor subtypes. Brain Res Mol Brain Res 58:231-236

Levitt P, Moore RY (1978): Noradrenaline neuron innervation of the neurocortex in the rat. Brain Res 139:219-231

Lewis DA, Campbell MJ, Foote SL, Goldstein M, Morrison JH (1987): The distribution of tyrosine hydroxylase immunoreactive fibers in primate neocortex is widespread but regionally specific. J Neurosci 7:279-290

Lin CS, Nicolelis MA, Schneider JS, Chapin JK (1990): A major direct GABAergic pathway from zona incerta to neocortex. Science 248:1553-1556

Lin RC, Nicolelis MA, Chapin JK (1997): Topographic and laminar organizations of the incertocortical pathway in rats. Neuroscience 81:641-651

Lindvall O, Bjorklund A (1978): Anatomy of the dopaminergic neuron systems in the rat brain. In Roberts PJ (ed), Advances in Biochemical Psychopharmacology. New York, Raven Press, pp 1-23
Lindvall O, Bjorklund A (1984): General organization of cortical monoamine systems. In Descarries L, Reader TR, Jasper HH (eds), Monoamine Innervation of Cerebral Cortex. New York, Alan R. Liss, pp 9-40

Ling D, Benardo L (1995): Recruitment of GABAA inhibition in rat neocortex is limited and not NMDA dependent. J Neurophysiol 74:2329-2335

Litwak J, Mercugliano M, Chesselet MF, Oltmans GA (1990): Increased glutamic acid decarboxylase (GAD) mRNA and GAD activity in cerebellar Purkinje cells following lesion-induced increases in cell firing. Neurosci Lett 116:179-183

Longson D, Deakin JF, Benes FM (1996): Increased density of entorhinal glutamate-immunoreactive vertical fibers in schizophrenia. J Neural Transm 103:503-507

Maccaferri G, McBain CJ (1996): Long-term potentiation in distinct subtypes of hippocampal nonpyramidal neurons. J Neurosci 16:5334-5343

Majewska MD, Bisserbe J-C, Eskay LR (1985): Glucocorticoids are modulators of GABAA receptors in brain. Brain Res 339:178-182

Marin-Padilla M (1984): Neurons of layer I. A developmental analysis. In Peter A, Jones EG (eds), Cerebral Cortex. New York, Plenum Press, pp 447-478

Martin DL, Martin SB, Wu SJ, Expina N (1993): Regulatory properties of brain glutamate decarboxylase (GAD): The apoenzyme of GAD is present principally as the smaller of the two molecular forms of GAD in the brain. J Neurosci 11:2725-2731

Marty S, Berninger B, Carroll P, Thoenen H (1996): GABAergic stimulation regulates the phenotype of hippocampal interneurons through the regulation of brain-derived neurotrophic factor. Neuron 16:565-570

Matussek P (1951): Untersuchunger uber die wahnwahrenmung. I Mitteilung: Verangerunger der Wahrenhmungswelt bei beginnenden, primaren Wahn. Arch Psychiat Nervenkl 189:279-319

McEwen B (1982): Glucocorticoids and hippocampus: Receptors in search of a function. In Ganten D, Pfaff D (eds). Current topics in neuroendocrinology Vol. 2. Springer, New York, pp 1-22

McGhie A, Chapman J (1961): Disorders of attention and perception in early schizophrenia. Brit J Med Psychol 34:103-116

McMahon LL, Kauer JA (1997): Hippocampal interneurons express a novel form of synaptic plasticity. Neuron 18:295-305

Mesulam M-M, Mufson EJ, Levey AI, Wainer BH (1983): Cholinergic innervation of cortex by the basal forebrain: Cytochemistry and cortical connections of the septal area, diagonal band nuclei, nucleus basals (Substantia innominata) and hypothalamus in the rhesus monkey. J Comp Neurol 214:140-191

Miles RK, Toth K, Gulyas AI, Hajas N, Freund TF (1996): Differences between somatic and dendritic inhibition in the hippocampus. Neuron 16:815-823

Miller AL, Chaptal C, McEwen BS, Beck JRE (1978): Modulation of high affinity GABA uptake into hippocampal synaptosomes by glucocorticoids. Psychoneuroendocrinology 3:155-164 
Miller LP, Walters JR, Martin DL (1991): Post-mortem changes implicate adenine nucleotides and puridoxal5 '-phosphate in regulation of brain glutamate decarboxylase. Nature 266:847-848

Morilak DA, Garlow SJ, Ciaranello RD (1993): Immunocytochemical localization and description of neurons expressing 5-HT-2 receptors in the rat brain. Neuroscience $54: 701-717$

Muly EC 3rd, Szigeti K, Goldman-Rakic PS (1998): D1 receptor in interneurons of macaque prefrontal cortex: Distribution and subcellular localization. J Neurosci 18:10553-10565

Noack HJ, Lewis DA (1989): Antibodies directed against tyrosine hydroxylase differentially recognize noradrenergic axons in monkey neocortex. Brain Res 500:313-324

O'Connor LN, Brene S, Herrera-Marschitz M, Persson H, Ungerstedt U (1991): Short-term dopaminergic regulation of GABA release in dopamine deafferentated caudate-putamen is not directly associated with glutamic acid decarboxylase gene expression. Neurosci Lett 128:66-70

O'Kusky J, Colonnier M (1982): A laminar analysis of the number of neurons, glia, and synapses in the adult cortex (area 17) of adult macaque monkeys. J Comp Neurol 210:278-290

Ongur D, Drevets WC, Price JL (1998): Glial reduction in the subgenual prefrontal cortex in mood disorders. Proc Natl Acad Sci U S A 95:13290-13295

Payne RW, Friedlander D (1962): Short battery of simple tests for measuring over-inclusive thinking. J Ment Sci 108:362-367

Payne RW, Matussek P, George EI (1961): Experimental study of schizophrenic thought disorder. Brit J Psychiatry 108:362-367

Perry TL, Buchanan J, Kish SJ, Hansen S (1979): Gammaaminobutyric acid deficiency in brains of schizophrenic patients. Lancet 1:237-239

Pesold C, Impagnatiello F, Pisu MG, Uzunov DP, Costa E, Guidotti, A (1998): Reelin is preferentially expressed in neurons synthesizing $\gamma$-aminobutyric acid in cortex and hippocampus in adult rats. Proc Natl Acad Sci U S A 95:3221-3226

Pesold C, Liu WS, Guidotti A, Costa E, Caruncho HJ (1999): Cortical bitufted, horizontal and martinotti cells preferentially express and secrete reelin into perineuronal nets, nonsynaptically modulating gene expression. Proc Natl Acad Sci U S A 96:3217-3222

Peters A (1984): Chandelier cells. In Peter A, Jones EG (eds), Cerebral Cortex. New York, Plenum Press, pp 361-380

Pfaff DW, Silva MTA, Weiss JM (1971): Telemeterred recording of hormone effects on hippocampal neurons. Science 172:394-395

Pierri JN, Chaudry AS, Woo TU, Lewis DA (1999): Alterations in chandelier neuron axon terminals in the prefrontal cortex of schizophrenic subjects. Am J Psychiatry 156:1709-1719

Pikkarainen MS, Ronkko S, Savander V, Insausti R, Pitkanen A (1999): Projections from the lateral, basal and accessory basal nuclei of the amygdalal to the hippocampal formation. J Compar Neurol 403:229-260
Rabow RSJ, Farb DH (1995): From ion currents to genomic analysis: Recent advances in GABAA receptor research. Synapse 21:189-274

Rall W (1970): Dendritic neuron theory and dendrodendritic synapsis in a simple cortical system. In Schmitt FO (ed), Neurosciences: Second Study Program. New York: Rockefeller Press

Ramon y Cajal S (1893): Estructura del asta de Ammon y fascia dentata. Ann Soc Esp Hist Nat 22

Ramon y Cajal S (1911): Histologie de Systeme Nerveux de 1'Homme et de Vertebrates. Trans. by L. Azouley. Paris; Maloine 2:772-779

Rao SG, Williams GV, Goldman-Rakic PS (1999): Isodirectional tuning of adjacent interneurons and pyramidal cells during working memory: Evidence for microcolumnar organization in PFC. J Neurophysiol 81:1903-1916

Rao SG, Williams GV, Goldman-Rakic PS (2000): Destruction and creation of spatial tuning by disinhibition: GABA(A) blockade of prefrontal cortical neurons engaged by working memory. J Neurosci 20:485-494

Retaux S, Besson MJ, Penit-Soria J (1991): Synergism between D1 and D2 dopamine receptors in the inhibition of the evoked release of $[3 \mathrm{H}] \mathrm{GABA}$ in the rat prefrontal cortex. Neuroscience 43:323-329

Reynolds GP (1983): Increased concentrations and lateral asymmetry of amygdala dopamine in schizophrenia. Nature 305:527-529

Reynolds GP, Czudek C, Andrews H (1990): Deficit and hemispheric asymmetry of GABA uptake sites in the hippocampus in schizophrenia. Biol Psychiatry 27:1038-1044

Roberts E (1972): An hypothesis suggesting that there is a defect in the GABA system in schizophrenia. Neurosci Res Progr Bull 10:468-482

Roth RH, Tam SY, Ida Y, Yang JX, Deutch AY (1988): Stress and the mesocorticolimbic dopamine systems. Ann N Y Acad Sci 537:138-147

Saccuzzo DP, Braff DL (1986): Information-processing abnormalities: Trait-and state-dependent component. Schiz Bull 12:447-456

Samson Y, Wu JJ, Friedman AH, Davis JN (1990): Catecholaminergic innervation of the hippocampus in the cynomolgus monkey. J Comp Neurol 298:250-263

Sapolsky RM (1992): Stress, the aging brain, and the mechanisms of neuron death. Cambridge, MA, MIT Press

Schwarcz R, Coyle JT (1977): Neurochemical sequelae of kainate injections in corpus striatum and substantia nigra of the rat. Life Sci 20:431-436

Selemon LD, Rajkowska G, Goldman-Rakic PS (1995): Abnormally high neuronal density in the schizophrenic cortex. A morphometric analysis of prefrontal area 9 and occipital area 17. Arch Gen Psychiatry 52:805-818

Selemon LD, Rajkowska G, Goldman-Rakic PS (1998): Elevated neuronal density in prefrontal area 46 in brains from schizophrenic patients: Application of a threedimensional, stereologic counting method. J Comp Neurol 392:402-412

Sheldon PW, Aghajanian GK (1990): Serotonin (5-HT) induces IPSPs in pyramidal layer cells of rat piriform cortex: Evidence for the involvement of a 5-HT2-activated interneuron. Brain Res 506:62-69 
Sheldon PW, Aghajanian GK (1991): Excitatory responses to serotonin (5-HT) in neurons of the rat piriform cortex: Evidence for mediation by 5 -HT1C receptors in pyramidal cells and 5-HT2 receptors in interneurons. Synapse 9:208-218

Sillito AM (1975): The contribution of inhibitory mechanisms to the receptive field properties of neurons in the striate cortex. J Physiol 250:305-329

Sillito AM (1984): Functional considerations of the operation of GABAergic inhibitory processes in the visual cortex. In Peter A, Jones EG (eds), Cerebral Cortex. New York, Plenum Press, pp 91-117

Simpson MD, Slater P, Deakin JF (1998): Comparison of glutamate and gamma-aminobutyric acid uptake binding sites in frontal and temporal lobes in schizophrenia. Biol Psychiatry 44:423-427

Simpson MD, Slater P, Deakin JF, Royston MC, Skan WJ (1989): Reduced GABA uptake sites in the temporal lobe in schizophrenia. Neurosci Lett 107:211-215

Smiley JF, Goldman-Rakic PS (1996): Serotonergic axons in monkey prefrontal cerebral cortex synapse predominantly on interneurons as demonstrated by serial section electron microscopy. J Comp Neurol 367:431-443

Smiley JF, McGinnis JP, Javitt DC (2000): Nitric oxide synthase interneurons in the monkey cerebral cortex are subsets of the somatostatin, neuropeptide $Y$, and calbindin cells. Brain Res 863:205-212

Soltesz I, Deschenes M (1993): Low- and high-frequency membrane potential oscillations during theta activity in CA1 and CA3 pyramidal neurons of the rat hippocampus under ketamine-xylazine anesthesia. J Neurophysiol 70:97-116

Somogyi P (1979): A specific axo-axonal neuron in the visual cortex of the rat. Brain Res 195:547-566

Somogyi P, Cowey A (1981): Combined Golgi and electron microscopic study on the synapses formed by double bouquet cells in the visual cortex of the cat and monkey. J Comp Neurol 195:547-566

Somogyi P, Cowey A (1984): Double bouquet cells. In Peter A, Jones EG (eds), Cerebral Cortex. New York, Plenum Press, pp 337-360

Somogyi P, Freund TF, Cowey A (1982): The axo-axonic interneuron in the cerebral cortex of the rat, cat and monkey. Neuroscience 7:2577-2607

Somogyi P, Tamas G, Lujan R, Buhl EH (1998): Salient features of synaptic organisation in the cerebral cortex. Brain Res Brain Res Rev 26:113-135

Somogyi P, Smith AD, Nunzi MG, Gorio A, Takagi H, Wu JY (1983): Glutamate decarboxylase immunoreactivity in the hippocampus of the cat: distribution of immunoreactive synaptic terminals with special reference to the axon initial segment of pyramidal neurons. J Neurosci 3:1450-1468

Somogyi P, Freund TF, Hodgson AJ, Somogyi J, Beroukas D, Chubb IW (1985): Identified axo-axonic cells are immunoreactive for GABA in the hippocampus and visual cortex of the cat. Brain Res 332:143-149

Soriano E, Frotscher M (1989): A GABAergic axo-axonic cell in the fascia dentata controls the main excitatory hippocampal pathway. Brain Res 503:170-174
Spike RC, Todd AJ, Johnston HM (1993): Coexistence of NADPH diaphorase with GABA, glycine, and acetylcholine in rat spinal cord. J Comp Neurol 335:320-333

Squires RF, Lajtha A, Saederup E, Palkovits M (1993): Reduced [3-H]-Flunitrazepam bindings in cingulate cortex and hippocampus of postmortem schizophrenic brains. Neurochem Res 18:219-223

Steriade M (1999): Coherent oscillations and short-term plasticity in corticothalamic networks. Trends Neurosci 22:337-345

Stone DJ, Walsh J, Benes FM (1999): Localization of cells preferentially expressing $\mathrm{GAD}(67)$ with negligible $\mathrm{GAD}(65)$ transcripts in the rat hippocampus. A double in situ hybridization study. Brain Res Mol Brain Res 71:201-209

Stone DJ, Walsh JP, Benes FM (2001): Effects of pre- and postnatal stress on the rat GABA system. Neuropsychopharm, in press

Stumpf WE, Heiss C, Sar M, Duncan GE, Draver C (1989): Dexamethasone and corticosterone receptor sites. Histochemistry 92:201-210

Sutanto W, Handelmann G, de Bree F, de Kloet ER (1989): Multifaceted interaction of corticosteroids with the intracellular receptors and with membrane GABAA receptor complex in the rat brain. J Neuroendocrinol $1: 243-247$

Szentagothai J, Arbib MA (1974): Conceptual models of neural organization. Neurosci Res Program Bull 12:305-510

Takahashi M, Shirakawa O, Toyooka K, Kitamura N, Hashimoto T, Maeda K, Koizumi S, Wakabayashi K, Takahashi H, Someya T, Nawa H (2000): Abnormal expression of brain-derived neurotrophic factor and its receptor in the corticolimbic system of the schizophrenic patients. Mol Psychiatry 5:293-300

Taylor JB, Benes FM (1996): Colocalization of glutamate decarboxylase, tyrosine hydroxylase and serotonin immunoreactivity in rat medial prefrontal cortex. Neuroscience-Net 1:10001

Thierry AM, Tassin JP, Blanc G, Glowinski J (1976): Selective activation of the mesocortical DA system by stress. Nature 263:242-244

Thierry AM, Blanc G, Sobel A, Stinus L, Glowinski J (1973): Dopaminergic terminals in the rat cortex. Science 182:499-501

Thomson AM, Deuchars J (1994): Temporal and spatial properties of local circuits in neocortex. Trends Neurosci 17:119-126

Thomson AM, Deuchars J (1997): Synaptic interactions in neocortical local circuits: Dual intracellular recordings in vitro. Cereb Cortex 7:510-522

Todtenkopf MS, Benes FM (1998): Distribution of glutamate decarboxylase 65 immunoreactive puncta on pyramidal and nonpyramidal neurons in hippocampus of schizophrenic brain. Synapse 29:323-332

Traub RD, Jefferys JG, Whittington MA (1997): Simulation of 
gamma rhythms in networks of interneurons and pyramidal cells. J Comput Neurosci 4:141-150

Tsubokawa H, Ross WN (1996): IPSPs modulate spike backpropagation and associated $[\mathrm{Ca} 2+] \mathrm{i}$ changes in the dendrites of hippocampal CA1 pyramidal neurons. J Neurophysiol 76:2896-2906

Tsumoto T, Eckart W, Creutzfeldt OD (1979): Modifications of orientation sensitivity of cat visual cortex neurons by removal of GABA-mediated inhibition. Exp Brain Res 34:351-363

Valtschanoff JG, Weinberg RJ, Kharazia VN, Nakane M, Schmidt HH (1993a): Neurons in rat hippocampus that synthesize nitric oxide. J Comp Neurol 331:111-121

Valtschanoff JG, Weinberg RJ, Kharazia VN, Schmidt HH, Nakane M, Rustioni A (1993b): Neurons in rat cerebral cortex that synthesize nitric oxide: NADPH diaphorase histochemistry, NOS immunocytochemistry, and colocalization with GABA. Neurosci Lett 157:157-161

Van Hoesen GW, Morecraft RJ, Vogt BA (1993): Connections of the monkey cingulate cortex. In Vogt BA, Gabriel M (eds), Neurobiology of Cingulate Cortex and Limbic Thalamus. Boston, Birkhauser, pp 249-284

Verhoeff NP, Soares JC, D'Souza CD, Gil R, Degen K, AbiDargham A, Zoghbi SS, Fujita M, Rajeevan N, Seibyl JP, Krystal JH, van Dyck CH, Charney DS, Innis RB (1999): [123I]Iomazenil SPECT benzodiazepine receptor imaging in schizophrenia. Psychiatry Res 91:163-173

Verney C, Alvarez C, Gerrard M, Berger B (1990): Ultrastructural double-labelling study of dopamine terminals and GABA-containing neurons in rat anteromedial cortex. Eur J Neurosci 2:960-972

Verney C, Berger B, Adrien J, Vigny A, Gay M (1982): Development of the dopaminergic innervation of the rat cerebral cortex. A light microscopic immunocytochemical study using anti-tyrosine hydroxylase antibodies. Brain Res 281:41-52

Vernier P, Julie JF, Ratabou P, Fourrier O, Feuerstein C, Mallet J (1988): Similar time course changes in striatal levels of glutamic acid decarboxylase and proenkephalin mRNA following dopamineergic deafferentation in the rat. J Neurochem 51:1375-1380

Vincent SL, Khan Y, Benes FM (1993): Cellular distribution of dopamine D1 and D2 receptors in rat medial prefrontal cortex. J Neurosci 13:2551-2564

Vincent SL, Pabreza L, Benes FM (1995): Postnatal maturation of GABA-immunoreactive neurons of rat medial prefrontal cortex. J Comp Neurol 355:81-92

Vincent SL, Khan Y, Benes FM (1995): Cellular colocalization of dopamine D1 and D2 receptors in rat medial prefrontal cortex. Synapse 19:112-120

Vincent SL, Adamec E, Sorensen I, Benes FM (1994b): The effects of chronic haloperidol administration on GABAimmunoreactive axon terminals in rat medial prefrontal cortex. Synapse 17:26-35

Volk DW, Austin MC, Pierri JN, Sampson AR, Lewis DA (2000): Decreased glutamic acid decarboxylase67 messenger RNA expression in a subset of prefrontal cortical gamma-aminobutyric acid neurons in subjects with schizophrenia. Arch Gen Psychiatry 57:237-245

Wang Y, Fujita I, Murayama Y (2000): Neuronal mechanisms of selectivity for object features revealed by blocking inhibition of inferotemporal cortex. Nature Neurosci 3:807-813

Wassef AA, Dott SG, Harris A, Brown A, O’Boyle M, Meyer WJ 3rd, Rose RM (1999): Critical review of GABA-ergic drugs in the treatment of schizophrenia. J Clin Psychopharmacol 19:222-232

Whittington MA, Traub RD, Jefferys JG (1995): Synchronized oscillations in interneuron networks driven by metabotropic glutamate receptor activation. Nature 373:612-615

Williams SM, Goldman-Rakic PS (1993): Characterization of the dopaminergic innervation of the primate frontal cortex using a dopamine-specific antibody. Cereb Cortex 3:199-222

Wilson FA, O'Scalaidhe SP, Goldman-Rakic PS (1994): Functional synergism between putative gamma-aminobutyrate-containing neurons and pyramidal neurons in prefrontal cortex. Proc Natl Acad Sci U S A 91:4009-4013

Woo TU, Miller JL, Lewis DA (1997): Schizophrenia and the parvalbumin-containing class of cortical local circuit neurons. Am J Psychiatry 154:1013-1015

Woo TU, Whitehead RE, Melchitzky DS, Lewis DA (1998): A subclass of prefrontal gamma-aminobutyric acid axon terminals are selectively altered in schizophrenia. Proc Natl Acad Sci U S A 95:5341-5346

Woodbury DM (1952): Effects of adrenal steroids: Separability of anticonvulsant from hormonal effects. J Pharmacol Exp Therap 153::337-343

Wu C, Yoder EJ, Shih J, Chen K, Dias PK, Shi L, Ji SD, Wei J, Conner JM, Kumar S, Ellisman MH, Singh SK (1998): Development and characterization of monoclonal antibodies specific to serotonin 5-HT2A receptor. J Histochem Cytochem 46:811-824

Ylinen A, Soltesz I, Bragin A, Penttonen M, Sik A, Buzsaki G (1995a): Intracellular correlates of hippocampal theta rhythm in identified pyramidal cells, granule cells, and basket cells. Hippocampus 5:78-90

Ylinen A, Bragin A, Nadasdy Z, Jando G, Szabo I, Sik A, Buzsaki G (1995b): Sharp wave-associated high-frequency oscillation $(200 \mathrm{~Hz})$ in the intact hippocampus: network and intracellular mechanisms. J Neurosci 15:30-46 